\title{
Incremental testing of the Community Multiscale Air Quality (CMAQ) modeling system version 4.7
}

\author{
K. M. Foley ${ }^{1}$, S. J. Roselle ${ }^{1}$, K. W. Appel ${ }^{1}$, P. V. Bhave ${ }^{1}$, J. E. Pleim ${ }^{1}$, T. L. Otte ${ }^{1}$, R. Mathur ${ }^{1}$, G. Sarwar ${ }^{1}$, \\ J. O. Young ${ }^{1}$, R. C. Gilliam ${ }^{1}$, C. G. Nolte ${ }^{1}$, J. T. Kelly ${ }^{1, *}$, A. B. Gilliland ${ }^{1}$, and J. O. Bash ${ }^{1}$ \\ ${ }^{1}$ Atmospheric Modeling and Analysis Division, National Exposure Research Laboratory, Office of Research and \\ Development, US Environmental Protection Agency, RTP, NC, USA \\ *now at: Regional Air Quality Modeling Section, Planning and Technical Support Division, Air Resources Board, \\ California Environmental Protection Agency, Sacramento, CA, USA
}

Received: 29 September 2009 - Published in Geosci. Model Dev. Discuss.: 29 October 2009

Revised: 9 February 2010 - Accepted: 8 March 2010 - Published: 26 March 2010

\begin{abstract}
This paper describes the scientific and structural updates to the latest release of the Community Multiscale Air Quality (CMAQ) modeling system version 4.7 (v4.7) and points the reader to additional resources for further details. The model updates were evaluated relative to observations and results from previous model versions in a series of simulations conducted to incrementally assess the effect of each change. The focus of this paper is on five major scientific upgrades: (a) updates to the heterogeneous $\mathrm{N}_{2} \mathrm{O}_{5}$ parameterization, (b) improvement in the treatment of secondary organic aerosol (SOA), (c) inclusion of dynamic mass transfer for coarse-mode aerosol, (d) revisions to the cloud model, and (e) new options for the calculation of photolysis rates. Incremental test simulations over the eastern United States during January and August 2006 are evaluated to assess the model response to each scientific improvement, providing explanations of differences in results between $\mathrm{v} 4.7$ and previously released CMAQ model versions. Particulate sulfate predictions are improved across all monitoring networks during both seasons due to cloud module updates. Numerous updates to the SOA module improve the simulation of seasonal variability and decrease the bias in organic carbon predictions at urban sites in the winter. Bias in the total mass of fine particulate matter $\left(\mathrm{PM}_{2.5}\right)$ is dominated by overpredictions of unspeciated $\mathrm{PM}_{2.5}\left(\mathrm{PM}_{\text {other }}\right)$ in the winter and by underpredictions of carbon in the summer. The CMAQv4.7 model results show slightly worse performance for ozone predictions.
\end{abstract}

Correspondence to: K. M. Foley

(foley.kristen@epa.gov)
However, changes to the meteorological inputs are found to have a much greater impact on ozone predictions compared to changes to the CMAQ modules described here. Model updates had little effect on existing biases in wet deposition predictions.

\section{Introduction}

As part of the regulatory decision-making process for air quality management, the United States Environmental Protection Agency (USEPA) relies on numerical model simulations of the atmospheric chemistry and transport of airborne emissions and the resulting pollutant concentrations (Scheffe et al., 2007). Models, such as the Community Multiscale Air Quality (CMAQ) model (Byun and Schere, 2006), provide valuable information about the potential effects of emission control strategies (e.g., Fann et al., 2009) and changing climate (e.g., Nolte et al., 2008b). Such modeling studies are used to facilitate air quality management decisions that potentially have an important impact on human and ecosystem health. Hence, the air quality modeling community needs to continually update operational modeling systems with stateof-the-science knowledge of the atmospheric processes affecting air pollution levels in the United States.

Over the last ten years, new versions of the CMAQ model have been periodically released. Each new version consists of multiple updates to the model's scientific algorithms and input data quality. Since CMAQ is used by the USEPA, as well as State and Regional offices, to estimate criteria pollutant (e.g. ozone, $\mathrm{O}_{3}$; fine particulate matter, $\mathrm{PM}_{2.5}$ )

Published by Copernicus Publications on behalf of the European Geosciences Union. 
Table 1. Summary of 5 scientific and structural changes to CMAQv4.7 discussed in Sect. 4.

\begin{tabular}{lll}
\hline Increment & Description & Reference \\
\hline Base Model & CMAQ version 4.6 release. & Pleim et al. (2006) \\
$\gamma \mathrm{N}_{2} \mathrm{O}_{5}$ Increment & Updates to the heterogeneous $\mathrm{N}_{2} \mathrm{O}_{5}$ parameterization. & Davis et al. (2008) \\
SOA Increment & Improved treatment of secondary organic aerosol. & Carlton et al. (2010) \\
Coarse Mode Increment & Inclusion of dynamic mass transfer for coarse-modeaerosol. & Kelly et al. (2009) \\
Cloud Increment & Revisions to the cloud model. & \\
$\begin{array}{l}\text { Photolysis Increment } \\
\text { Previous Increment }\end{array}$ & New options for the calculation of photolysis rates. & Binkowski et al. (2007) \\
\hline
\end{tabular}

concentrations, each new release requires a comprehensive evaluation to establish model credibility for a wide range of applications (e.g. Mebust et al., 2003; Eder and Yu, 2006; Appel et al., 2007, 2008). Most recently, the CMAQ modeling system version 4.7 (v4.7) has been tested and evaluated against observations and was publicly released in December 2008 (http://www.cmaq-model.org/).

The scientific upgrades in v4.7 include the added capability to use meteorological input fields from the Weather Research and Forecasting (WRF; Skamarock et al., 2008) model, major changes to the treatment of aerosol, improvements in the resolved and convective cloud modules, updates to the chemistry modules based on recent field and modeling studies, and new options for processing emissions and calculating dry deposition velocities during the model execution (i.e., "in-line"). Rather than updating the CMAQ modeling system with all of these changes at one time, each major scientific update in this release was incrementally tested for two month-long periods (January and August 2006) and evaluated against observations. This approach, although time and resource intensive, allowed for a diagnostic evaluation of the individual model updates. Incremental testing showed the effect of each scientific improvement on the simulated fields of various pollutants and provided an opportunity for a clear explanation of differences between the results from current and previous model versions. This systematic approach also facilitated quality assurance and quality control of model simulations, input data, and implementation.

The following section provides a brief description of the major scientific and structural improvements included in CMAQv4.7. The model configuration and observational data sets used in the model evaluation are provided in Sect. 3. The evaluation is then presented in two parts. Section 4 documents the evaluation of five specific changes that were isolated as part of the overall incremental testing of the model: (a) changes to the heterogeneous $\mathrm{N}_{2} \mathrm{O}_{5}$ parameterization, (b) improvement in treatment of secondary organic aerosol (SOA), (c) inclusion of dynamic mass transfer for coarsemode aerosol, (d) revisions to the cloud model, and (e) new options for the calculation of photolysis rates. Table 1 lists these increments and the labeling scheme used throughout the paper to facilitate the discussion of the differences between each model update. These five increments were chosen as the focus of this paper because they represent a fundamental change from the previously released model version and had the propensity to impact model performance for criteria pollutants. The second portion of the evaluation, presented in Sect. 5, summarizes the overall change in model performance of CMAQv4.7 compared to the previously released version. Finally, Sect. 6 provides a discussion of future model development needs.

\section{Review of scientific and structural upgrades in CMAQv4.7}

Upgrades to the CMAQ v4.7 model are the culmination of many years of scientific advancements derived from laboratory, field and numerical experiments. Given the large community of CMAQ model users and the relatively small group of model developers, there are never sufficient resources to diagnose and address every issue in the modeling system that has been reported. Therefore, areas for model development were selected by carefully weighing a number of considerations including the findings from operational evaluations of past model versions, reviews of relevant literature on emerging issues of atmospheric importance, maturity of the underlying science, availability of relevant expertise within our team to address the issue, urgency of regulatory needs, recommendations from independent peer reviews of the CMAQ model (e.g., Aiyyer et al., 2007), and requests from the external community of CMAQ model users. The following discussion of each of the scientific upgrades is intended to provide an overview of the CMAQ v4.7 model, offering more background information than is available in the notes which accompany the $\mathrm{v} 4.7$ code release (http://www.cmaq-model.org/) and pointing the reader to additional resources for further details. 


\subsection{Meteorological input model}

The CMAQ system generally relies upon meteorological fields that can be generated from well-tested, state-of-thescience, community-based meteorological models. Previously released versions of CMAQ were tailored toward using the fifth-generation Pennsylvania State University/National Center for Atmospheric Research (NCAR) Mesoscale Model (MM5; Grell et al., 1994) as the source of input meteorological fields. In CMAQv4.7, the system was expanded to use meteorological fields from the WRF model. Although the WRF model has been available from NCAR as a "replacement" for MM5 for several years, scientific options that are critical for retrospective air quality simulations were lacking from the WRF model. For example, the use of continuous data assimilation via Newtonian relaxation (i.e., nudging) in the meteorological model has been shown to improve retrospective simulations with the air quality model (Otte, 2008a, b). In addition, the Asymmetric Convective Model version 2 (ACM2) for the planetary boundary layer (PBL) addresses atmospheric issues that are particularly important for nearsurface chemical transport modeling (Pleim, 2007), and it is used in both the meteorological and chemical transport models to maximize physical consistency. Also, the Pleim-Xiu land-surface model (PX LSM) (Xiu and Pleim, 2001; Pleim and Xiu, 2003; Pleim and Gilliam, 2009) was developed to accurately model surface heat and moisture fluxes from soil and vegetation and provide key parameters for chemical dry deposition. Nudging, the ACM2, and the PX LSM have all been available in MM5 for several years and were deemed critical for CMAQ simulations. These three critical features are all available in the WRF public release beginning with version 3.0.

CMAQ's Meteorology-Chemistry Interface Processor (MCIP; Otte and Pleim, 2009) was also upgraded to support output from the WRF model. MCIP's functions are to ingest the meteorological model fields, recast information in forms conforming to CMAQ's generalized coordinate formulation, diagnose additional atmospheric fields, and generate output in a format that can be used by the CMAQ system. Significant changes were required to MCIP to ingest and prepare the WRF model output for the CMAQ system, since the WRF model uses different state equations, fields, file formats, and vertical coordinate systems than MM5. In addition, the computation of dry deposition velocities that was previously calculated in MCIP was moved to the CMAQ chemical transport model (CCTM) as part of the new "in-line" code structure for surface fluxes in CMAQ (see Sect. 2.5). MCIP version 3.4.1 was released as a companion to the CMAQv4.7 software package (http://www.cmaq-model.org).

In two companion studies, multiple MM5 and WRF model simulations were performed for winter and summer months to examine the sensitivity of CMAQ model predictions to the output from each meteorological model. Gilliam and Pleim (2009) compared MM5 and WRF predictions for 2-m temperature, 2-m mixing ratio, 10-m winds and PBL features to observed meteorological data. Appel et al. (2009) evaluated CMAQ output for ozone, $\mathrm{PM}_{2.5}$ species, and wet deposition using MM5-based and WRF-model-based meteorology inputs. While MM5 and WRF error statistics that consider the entire model domain are comparable, there are regional differences in meteorology that are also reflected in the air quality model, as noted by Appel et al. (2009). Although MM5 and WRF do not produce the exact same model results, these studies demonstrated that the WRFmodel-based simulations generated comparable quality meteorological fields and air quality fields to the MM5-based simulations. The model evaluation provided confidence in the use of WRF model outputs for CMAQ simulations. In addition, the comparable performance of CMAQ when using either MM5-based or WRF-model-based meteorology fields demonstrated the versatility of the CMAQ system.

\subsection{Scientific improvements in the CMAQv4.7 aerosol treatment}

Changes within the CMAQ aerosol module can be divided into three main increments: updates to the heterogeneous $\mathrm{N}_{2} \mathrm{O}_{5}$ hydrolysis parameterization, improved treatment of secondary organic aerosol (SOA) formation, and a new treatment of gas-to-particle mass transfer for coarse aerosol. During winter months, model predictions of particulate nitrate are sensitive to the nighttime hydrolysis of $\mathrm{N}_{2} \mathrm{O}_{5}$ on particle surfaces (Dentener and Crutzen, 1993). The probability of

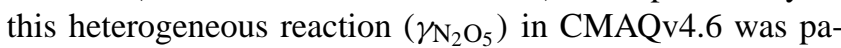
rameterized in part using a temperature- and $\mathrm{RH}$-dependent equation published by Evans and Jacob (2005). Lab data indicate that $\gamma_{\mathrm{N}_{2} \mathrm{O}_{5}}$ decreases with increased temperature; however this relationship was reversed in the published formula due to a typographical error (M. Evans, personal communication, 2006). After the release of v4.6, we discovered this typographical error had been copied directly into the CMAQ code (Davis et al., 2008). Correction of the error degraded the CMAQ predictions of wintertime nitrate, which subsequently motivated the need for an improved treatment of $\gamma_{\mathrm{N}_{2} \mathrm{O}_{5}}$. In CMAQv4.7, $\gamma_{\mathrm{N}_{2} \mathrm{O}_{5}}$ has been updated based on the parameterization given in Appendix A of Davis et al. (2008). This new parameterization is based on a more comprehensive set of laboratory data and is now a function of temperature, $\mathrm{RH}$ and inorganic particle composition. See Davis et al. (2008) for a complete description of the parameterization and comparisons with laboratory and ambient data. The evaluation of this update (referred to as $\gamma \mathrm{N}_{2} \mathrm{O}_{5}$ Increment) is given in Sect. 4.1.

The second update to the aerosol module adds several new SOA formation pathways to the CMAQ modeling system. Previous CMAQ model evaluations revealed a persistent negative bias in the prediction of summertime particulate carbon (e.g., Bhave et al., 2007; Appel et al., 2008) and it was hypothesized that the addition of newly-discovered SOA 
formation pathways to CMAQ would mitigate this bias (Morris et al., 2006). In addition, USEPA was keenly interested in quantifying the potential health benefit from reducing the aromatic content of gasoline through the use of ethanol blends (EPA, 2009). This motivated a need to incorporate the most up-to-date scientific information on aromatic SOA formation into CMAQ v4.7. The new pathways in v4.7 include SOA formation from isoprene, sesquiterpenes, benzene, glyoxal, and methylglyoxal. The revised model treats the acidcatalyzed enhancement of SOA mass, oligomerization reactions, aqueous-phase SOA formation, and $\mathrm{NO}_{\mathrm{X}}$-dependent SOA yields from aromatic compounds. Enthalpies of vaporization for each SOA type and ratios of SOA mass to organic carbon have been revised based on recent laboratory experiments (Offenberg et al., 2006; Kleindienst et al., 2007). Each gas-phase chemical mechanism released with the CMAQ model has been revised to include explicit reactions for the oxidation of benzene and sesquiterpenes. As part of this effort, the Biogenic Emissions Inventory System (BEIS) has been revised to compute emissions of sesquiterpenes as a function of temperature and plant functional type. New speciation files have been developed to distinguish the emissions of benzene from other aromatic VOCs, though future applications of the model may use benzene emissions directly from the hazardous air pollutants (HAPs) inventory. Detailed descriptions of the SOA updates are reported elsewhere (Carlton et al., 2008, 2009, 2010). Model results from this increment (SOA Increment) are evaluated in Sect. 4.2.

The third update to the aerosol module adds a new treatment of gas-to-particle mass transfer for coarse particles and updates the in-line treatment of sea-salt emissions. In earlier CMAQ model versions, the coarse particle mode was treated as chemically inert, with a fixed geometric standard deviation. Emission fluxes from the coastal surf zone were set equal to those from the open ocean. These simplifications hindered our ability to simulate aerosol composition in coastal urban areas and nutrient deposition to sensitive ecosystems (Nolte et al., 2008a). The new coarse-particle treatment in CMAQv4.7 allows sulfuric acid to condense on the coarse mode and allows semi-volatile inorganic species (ammonia, nitric acid, and hydrochloric acid) to condense and evaporate from the coarse mode. The water content of coarse particles is now determined by equilibrium with ambient RH and the size distribution of coarse particles is allowed to broaden and narrow as a result of microphysical processes. As in previous CMAQ model versions, the fine particle modes are assumed to reach equilibrium with the gas phase instantaneously. In contrast, dynamic mass transfer is simulated for the coarse mode because large particles are often out of equilibrium with the gas phase (Meng and Seinfeld, 1996). As a result, important aerosol processes such as the replacement of chloride by $\mathrm{NO}_{3}^{-}$in mixed marine/urban air masses can now be simulated. In conjunction with this update, the CMAQ input file OCEAN_1, has been enhanced to better allocate the fractions of each grid cell that are covered by land, open ocean, and coastal surf zone (see Foley et al., 2010a for further details). Emissions of sea salt from the coastal surf zone are then calculated by scaling up the open-ocean source function to mimic the flux from an area that is covered entirely by whitecaps. Detailed descriptions of these updates are provided by Kelly et al. (2009). Changes to coarse particle treatment are included in the Coarse Mode Increment and are evaluated in Sect. 4.3.

\subsection{Improvements to the CMAQv4.7 cloud model}

Updates were made to two components of the cloud model in CMAQ (cloud_acm): the grid-resolved cloud model and the sub-grid convective cloud model. The main update to the resolved cloud model was a correction to the vertical allocation of the precipitation flux. To compute wet deposition of pollutants, the resolved cloud model estimates which model layers contributed to the precipitation. CMAQ uses a simple algorithm to allocate precipitation amounts to individual layers based on a normalized profile of precipitating hydrometeors (rain, snow, and graupel). In the previously released versions of the CMAQ model, the precipitation flux was allocated into vertical model layers without consideration of the layer thickness. This had the effect of removing too much pollutant mass from thin layers and removing too little from the thick layers. In the CMAQv4.7 revised calculation, the precipitation flux for each layer is computed as a function of the non-convective precipitation rate, the sum of hydrometers and the layer thickness.

Sensitivity experiments identified several shortcomings in the sub-grid convective cloud model related to its application in areas with higher elevation (e.g., western United States) and in the selection of model vertical resolution. These issues were primarily a problem for $\mathrm{SO}_{4}^{2-}$ predictions. One set of experiments using 14, 24, and 34 layers showed that the model produced less ground-level $\mathrm{SO}_{4}^{2-}$ with increased vertical resolution during the summer. To address problems with the model in high elevation areas, the maximum allowable height for the source level of the convective parcel was changed from a fixed atmospheric pressure $(650 \mathrm{hPa})$ to $3 \mathrm{~km}$ above ground level (a.g.l.). The change was made to account for lower surface pressure in regions of high elevation. Another change was made to non-precipitating clouds by limiting their cloud tops to $3 \mathrm{~km}$ above cloud base rather than the previous $3 \mathrm{~km}$ a.g.l. This change affects cloud development in higher elevations where cloud bases are often much higher than in other areas.

To address model simulation consistency using different vertical resolutions, a change was made to the algorithm for finding the height of the cloud top. In previous versions of cloud_acm, the algorithm applied a perturbation to the temperature of the convective parcel to account for warm parcels that evolve into convective clouds. However, in simulations with a large number of vertical layers (e.g., 34), the temperature perturbation often causes the algorithm to 
erroneously assign the cloud top to the first layer above the cloud base. The result was unreasonably large differences in model simulations that used different vertical resolutions (e.g., 14 vs. 34). The perturbation temperature was removed from this calculation providing a greater degree of consistency among model runs using different vertical resolutions, which was confirmed by tests with 14,24 , and 34 vertical layers.

The treatment of sub-grid non-precipitating (NP) clouds was modified to allow NP clouds to exist only when the diagnosed lifting condensation level (LCL) is within the PBL. Previously, NP clouds were permitted when the cloud base was below $1.5 \mathrm{~km}$ a.g.l. This change is consistent with the idea that NP convective clouds have their roots in a turbulent boundary layer where buoyant air parcels can originate. The effect of this change is to greatly limit the occurrence of NP convective clouds at night over land and to sometimes enhance occurrence of NP convective clouds during afternoons when PBL heights can exceed $1.5 \mathrm{~km}$ a.g.l.

Another significant change was an improvement in process integration for convective clouds. Previously, convective clouds were modeled using a fixed time-step of one hour, regardless of horizontal grid resolution. For coarse grid resolutions (e.g., $\sim 80 \mathrm{~km}$ ), the assumption of a sub-grid cloud parameterization on a one hour timescale may be reasonable, however, for finer grids (e.g., $12 \mathrm{~km}$ ), horizontal advection may transport pollutants across several grid cells during the period of one hour, creating inconsistencies in how the cloud processes integrate with the other modeled processes. In version 4.7, the convective cloud model was revised to integrate convective clouds on the same process synchronization timestep used by the other process modules of emissions, advection, turbulent mixing, and chemistry.

In addition to the cloud physics changes, cloud chemistry was also updated. Organic species and oxidation reactions were incorporated into the aqueous chemical mechanism (Carlton, et al., 2008). Henry's Law constants for several species $\left(\mathrm{O}_{3}, \mathrm{NO}_{3}\right.$, hexane, octane, nonane, isoprene and methanol) were updated following an extensive literature review that is summarized in the CMAQ v4.7 release notes (http://www.cmaq-model.org/). Although the multiple changes to the cloud module were tested over several increments, they are evaluated in Sect. 4.4 as a single incremental change (Cloud Increment) in order to simplify the presentation of the results.

\subsection{Improvements in atmospheric chemistry}

This section outlines changes in CMAQv4.7 chemistry associated with nitrous acid (HONO), chlorine $\left(\mathrm{Cl}_{2}\right)$ and mercury $(\mathrm{Hg})$. Earlier versions of CMAQ significantly underestimated ambient HONO mixing ratios which also exhibited a diurnal profile opposite to that noted in limited available measurements. HONO is the largest source of $\mathrm{OH}$ radicals (which controls oxidation) during the morning hours.
Changes were made to the chemistry module and corresponding emissions inputs to CMAQ to improve the prediction of HONO in v4.7. The first change was in the speciation of $\mathrm{NO}_{\mathrm{x}}$ emissions from motor vehicles. An important source of HONO in the atmosphere is mobile source emissions; however, in previous versions of the Sparse Matrix Operator Kernel Emission (SMOKE) processor, $\mathrm{NO}_{\mathrm{x}}$ emissions from motor vehicles were speciated only into nitric oxide (NO) and nitrogen dioxide $\left(\mathrm{NO}_{2}\right)$. In SMOKE version 2.5, $\mathrm{NO}_{\mathrm{x}}$ emissions are speciated into $\mathrm{NO}, \mathrm{NO}_{2}$, and $\mathrm{HONO}$. Emissions of $\mathrm{NO}_{2}$ are appropriately reduced so that the sum of $\mathrm{NO}, \mathrm{NO}_{2}$, and $\mathrm{HONO}$ equals to $\mathrm{NO}_{\mathrm{x}}$. The new speciation uses a $\mathrm{HONO} / \mathrm{NO}_{\mathrm{x}}$ ratio of 0.008 based on measurements of HONO emissions in a road tunnel study (Kurtenbach et al., 2001). Recent studies suggest that heterogeneous reactions (involving $\mathrm{NO}_{2}$ and $\mathrm{H}_{2} \mathrm{O}$ ) on aerosol and ground surfaces can produce $\mathrm{HONO}$ in the atmosphere. The incorporation of these emissions and production pathways in CMAQv4.7 now results in improved representation of both the diurnal variability and the magnitude of predicted ambient HONO mixing ratios and its impact on atmospheric photochemistry (Sarwar et al., 2008). Because HONO observations for the time period of this study were not readily available, and the relative impacts of this change on ozone and PM predictions were small, no increment is presented in the paper.

A chlorine mechanism was implemented in CMAQ for use with the 2005 version of the Carbon Bond (CB05) mechanism (Yarwood et al., 2005). Recent studies suggest that anthropogenic and sea-salt derived chlorine emissions can affect $\mathrm{O}_{3}$ in some areas in the United States (Simon et al., 2009; Sarwar et al., 2007). The USEPA has developed a National Emissions Inventory (NEI) for HAPs that includes estimates of anthropogenic chlorine emissions. Chlorine chemistry has been combined with the CB05 mechanism and is used as a base mechanism in the CMAQ model. In addition to the base model, CMAQv4.7 also includes an optional multipollutant version (Roselle et al., 2007) that simulates $\mathrm{O}_{3}, \mathrm{PM}, \mathrm{Hg}$, and other HAPs in a single model configuration. The multipollutant model replaces the stand-alone model versions for air toxics (Hutzell and Luecken, 2008; Luecken et al., 2006) and $\mathrm{Hg}$ (Bullock and Brehme, 2002) from previous model releases.

\subsection{In-line processing options}

The CMAQ modeling system uses emissions inputs from the NEI and other sources that are processed using SMOKE. Two emissions processing schemes from SMOKE have been incorporated into CMAQ: biogenic emissions into the lowest vertical layer and plume rise of point-source emissions. These optional schemes allow the emissions to be meteorologically modulated at the synchronization (chemistry) timestep rather than being linearly time-interpolated within each simulation hour. In addition, these options allow the CMAQ model to be more consistently incorporated as an in-line 
component of a meteorology model (e.g., WRF), enabling direct emissions modulation by the most recently computed meteorological variables. Additionally, the in-line computation of plume-rise, significantly reduces the disk space requirements during model execution because the large 3$\mathrm{D}$ emission files can be substituted with 2-D files.

The new version of the CMAQ model now also calculates dry deposition velocities in-line by default, obviating the need for the MCIP to provide these input data. As with the emissions, deposition velocities are meteorologicallymodulated at the synchronization (chemistry) time-step rather than being linearly time-interpolated within each simulation hour. More importantly, this approach now provides a means to consistently formulate and simulate bi-directional pollutant fluxes to and from the surface.

\subsection{Research options}

This section describes research options available in the CMAQv4.7 release. While these options are considered "beta" versions, they are being provided to the community for testing and experimentation. One option for calculating photochemical rate constants is included in the incremental tests as a demonstration of capability.

Within the standard CMAQ photolysis module, clear-sky photolysis rates at specific altitudes, latitudes, and hour angles are computed offline with the photolysis rate preprocessor JPROC and read into the model as a look-up table. The clear-sky photolysis rates are then interpolated to model grid cells at specified time-steps and also adjusted for the presence of cloud cover. Two new options were included in CMAQv4.7 for computing photochemical rate constants. One option utilizes satellite-derived cloud information to adjust photolysis rates (Pour-Biazar et al., 2007). Predicting the location and amount of cloud cover has historically been one of the most difficult problems in numerical weather prediction and air quality modeling. Using cloud information derived from satellites should give a better representation of the cloud fields. At present, data from the Geostationary Operational Environmental Satellite (GOES) are archived for a limited area and time periods and may be obtained from the National Aeronautics and Space Administration (NASA)/National Space Science and Technology Center's Satellite Assimilation website (http://satdas.nsstc.nasa. gov/data.html). In addition, the preprocessing software is also available from the NASA website. An updated version of the preprocessing software is being developed, which regrids satellite data to the CMAQ modeling grid domain using the Spatial Allocator Tool (available from the Community Modeling and Analysis (CMAS) center, http://www.ie. unc.edu/cempd/projects/mims/spatial/). An incremental test using the satellite data revealed problems in the satellite regridding/preprocessing software, which are currently being addressed. Because of this problem, no analysis of this increment is presented here.
The second option for photolysis rate calculation is an inline module developed by Binkowski et al. (2007). The module computes photolysis rates using chemical/aerosol and meteorological information available for all modeled grid cells and layers; this enhancement allows for investigation of potentially important impacts of scattering and absorbing aerosols in modulating photolysis rates and atmospheric photochemistry regulating the formation of secondary air pollutants (cf., Dickerson et al., 1997). Some additional work is needed to implement temperature variation of the absorption cross section and quantum yield data for the CB05 and SAPRC99 (Carter, 2000) chemical mechanisms into the module. Evaluation of the CMAQ model using the in-line photolysis option is presented in Sect. 4.5 as the Photolysis Increment. Both photolysis options were released as "beta" versions because there is ongoing development to improve the software codes, and, therefore, neither option has been implemented in the default configuration of the model.

Research options were also included in CMAQv4.7 for bidirectional surface exchange of ammonia $\left(\mathrm{NH}_{3}\right)$ and $\mathrm{Hg}$. Emissions of $\mathrm{NH}_{3}$ from natural and managed agricultural surfaces and emissions of $\mathrm{Hg}$ through natural processes are controlled by environmental meteorological, physical and chemical parameters that can be meaningfully described in an air-surface exchange module (Sutton et al., 1998; Graydon et al., 2006). Mechanistic models of bidirectional exchange for $\mathrm{NH}_{3}$ and $\mathrm{Hg}$ were developed based on the "canopy compensation point" concept (Sutton et al., 1998). A "canopy compensation point" is defined as a function of the land cover type, ambient temperature, and partitioning of $\mathrm{NH}_{3}$ and $\mathrm{Hg}$ between atmospheric, apoplastic and vegetation surface compartments. Details of the implementation of the $\mathrm{Hg}$ bidirectional model are given in Bash (2010). The bidirectional mercury exchange option is available for the multipollutant version of CMAQ. Bidirectional surface exchange options are intended to replace $\mathrm{NH}_{3}$ and $\mathrm{Hg}$ emissions from natural surfaces, currently estimated a priori and included in the emissions inventory, and thus were not included in the incremental tests to avoid the double counting of inline emission estimates.

The following two sections present the description of the case study used to evaluate the main scientific updates to the CMAQv4.7 model and the results from each model change. Evaluation results are based on comparisons to observations as well as previous model versions.

\section{Modeling approach and observational data sets}

The modeling domain selected for testing the scientific updates encompasses the eastern United States using 279 grid cells East/West and 240 grid cells North/South, with a $12 \mathrm{~km}$ by $12 \mathrm{~km}$ horizontal grid spacing. The model simulations utilize 34 vertical layers extending up to $10 \mathrm{kPa}$, matching the vertical structure of the meteorological inputs. Hourly-averaged concentrations from the lowest model layer 
( $\sim 35 \mathrm{~m}$ thick) are used for comparison with observations. The CB05 chemical mechanism with chlorine chemistry was used in the model simulations. In order to test the model under seasonal extremes, a winter month (January) and summer month (August) from 2006 were simulated; in each case a 3-day model spin-up was used. All of the CMAQ simulations described here use the meteorological fields derived from the WRF model. Specifics on the configuration options used for the WRF model simulation can be found in Appel et al. (2009) and Gilliam and Pleim (2010). Boundary and initial conditions were specified from the output of simulations with $36 \mathrm{~km}$ by $36 \mathrm{~km}$ horizontal grid spacing across the entire continental United States for the same two months.

Emission inputs for these simulations were based on the USEPA NEI for 2001 (http://www.epa.gov/ttn/chief/net/ critsummary.html) and then projected to 2006 for select sectors. The raw emissions data were processed to generate gridded, hourly emissions fields using the latest released version of the SMOKE processor, version 2.5 (http://www. smoke-model.org/version $2.5 / \mathrm{html} /$ ). To estimate emissions for January and August 2006, the 2001 NEI was updated with observed 2006 point source emissions from electric generating units (EGUs) equipped with Continuous Emission Monitoring Systems (CEMS). Biogenic emissions were processed using the BEIS version 3.13 (Vukovich and Pierce, 2002; Schwede et al., 2005) and supplemented with sesquiterpene fluxes that were calculated using emission factors from the Model of Emission of Gases and Aerosols from Nature (MEGAN; Guenther et al., 2006) (see Foley et al., 2010a for further details). Mobile source emissions were estimated using the Mobile6 emission model (http://www.epa.gov/otaq/ m6.htm) within SMOKE. Both biogenic and mobile emissions were modulated based on hourly meteorological inputs from WRF.

Simulations from the CMAQ model are paired in time and space with observations from several national monitoring networks. These data include observations of $\mathrm{O}_{3}$ obtained for EPA's Air Quality System (AQS; http://www.epa.gov/ ttn/airs/airsaqs/); observations of aerosol particulate matter from the Interagency Monitoring of PROtected Environments (IMPROVE; http://vista.cira.colostate.edu/improve/) network, the Chemical Speciation Network (CSN; previously called the Speciation Trends Network, STN), and the Clean Air Status and Trends Network (CASTNet; http: //www.epa.gov/castnet/); observations of coarse particulate matter from the Southern Aerosol Research and Characterization Study (SEARCH; http://www.atmospheric-research. $\mathrm{com} /$ studies/SEARCH/index.html); and observations of precipitation, $\mathrm{SO}_{4}^{2-}, \mathrm{NO}_{3}^{-}$and ammonium $\left(\mathrm{NH}_{4}^{+}\right)$wet deposition from the National Atmospheric Deposition Program (NADP; http://nadp.sws.uiuc.edu/) network. Observations from the AQS are hourly values, observations from the SEARCH network are daily average values, CSN and IMPROVE network observations are daily average values available every third day, CASTNet observations are weekly average values, and the NADP network observations are monthly accumulated values. Additional details about the observation networks and how the data are paired with the CMAQ model predictions are available in Appel et al. (2007, 2008).

\section{Evaluation of major scientific increments}

The following section presents model evaluation results from four of the major scientific upgrades and one research option in CMAQv4.7 listed in Table 1. Additional incremental changes were tested that are not presented here. For clarity of presentation, "previous increment" is used as a label for some model-to-model comparisons to avoid additional notation for changes that are not the focus of this analysis (see Foley et al., 2010b for further details). Evaluation of each increment involved screening the impact of the change on several primary and secondary pollutants for quality control purposes. Here, we focus on the pollutant changes that are most relevant to the individual increment, using available observations and comparison to previous model versions. The concluding section provides a more general overview of the overall change in model performance for the set of pollutants most critical for informing air quality management decisions.

\subsection{New parameterization for heterogeneous reaction probability}

To understand the impact of correcting the error in the parameterization of $\gamma_{\mathrm{N}_{2} \mathrm{O}_{5}}$ in the CMAQ aerosol model (see Sect. 2.2), the difference between model output from the base and the corrected base model has been included in Fig. 1. Average nighttime $\gamma_{\mathrm{N}_{2}} \mathrm{O}_{5}$ values in January increase drastically over much of the region, resulting in increases in $\mathrm{TNO}_{3}$ $\left(\mathrm{NO}_{3}^{-}+\right.$nitric acid $\left.\left(\mathrm{HNO}_{3}\right)\right)$ concentrations up to $1.22 \mu \mathrm{g} / \mathrm{m}^{3}$, particularly in the Northeast and Midwest regions (compare first and second column of Fig. 1).

The effect of revising the $\gamma_{\mathrm{N}_{2}} \mathrm{O}_{5}$ parameterization $\left(\gamma \mathrm{N}_{2} \mathrm{O}_{5}\right.$ Increment) has maximum impact in regions of high $\mathrm{RH}$ and very low temperature. Compared to the corrected base model, the largest average differences in total nitrate $\left(\mathrm{TNO}_{3}\right)$ concentrations in the updated model simulations are on the order of $\pm 10 \%$ in January (on average, changes in $\mathrm{TNO}_{3}$

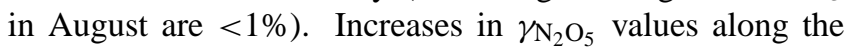
eastern seaboard and in the Southwest result in increases in monthly-average $\mathrm{TNO}_{3}$ up to $0.16 \mu \mathrm{g} / \mathrm{m}^{3}$. In colder northern areas, $\gamma_{\mathrm{N}_{2}} \mathrm{O}_{5}$ values are lower in the new model simulation, which results in a decrease in the $\mathrm{TNO}_{3}$ concentrations of up to $0.33 \mu / \mathrm{m}^{3}$ (third columns of Fig. 1). The apparent insensitivity of $\mathrm{TNO}_{3}$ concentrations to large changes in $\gamma_{\mathrm{N}_{2} \mathrm{O}_{5}}$ is largely due to the compensating effect of gas-phase chemistry (e.g., when the heterogeneous pathway is decreased by lowering $\gamma_{\mathrm{N}_{2} \mathrm{O}_{5}}$, the rate of gas-phase $\mathrm{N}_{2} \mathrm{O}_{5}$ hydrolysis increases). 

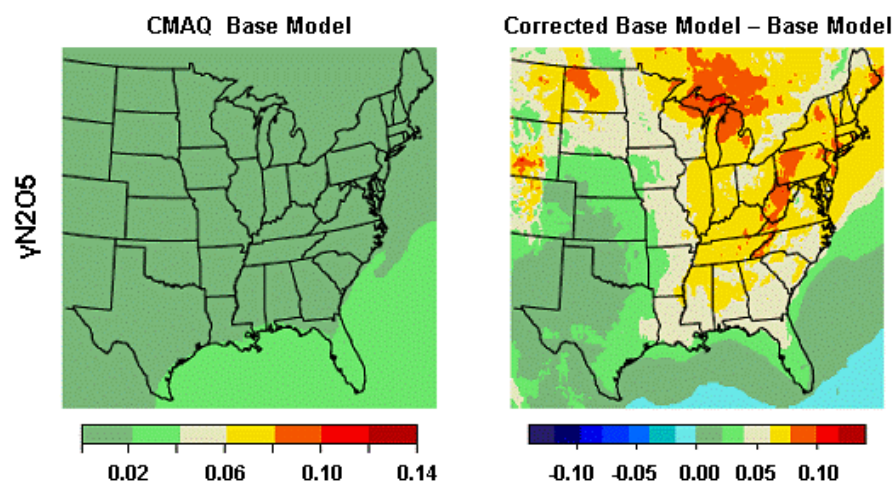

$\begin{array}{lllll}-0.10 & -0.05 & 0.00 & 0.05 & 0.10\end{array}$
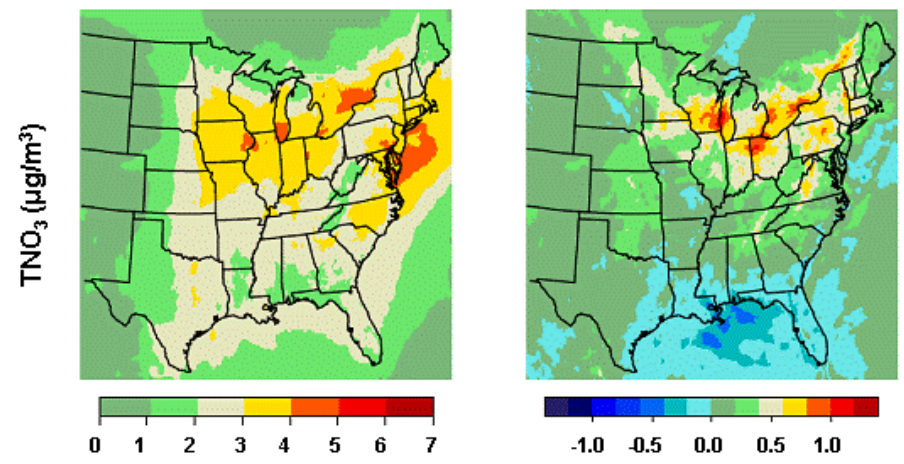

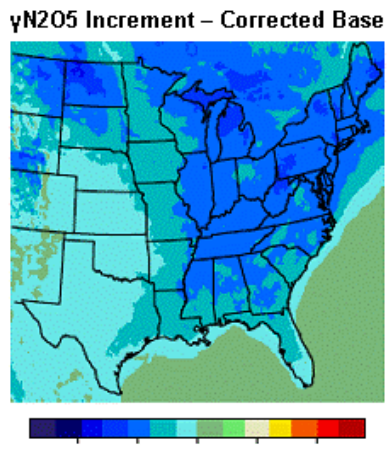

$\begin{array}{lllll}0.10 & -0.05 & 0.00 & 0.05 & 0.10\end{array}$

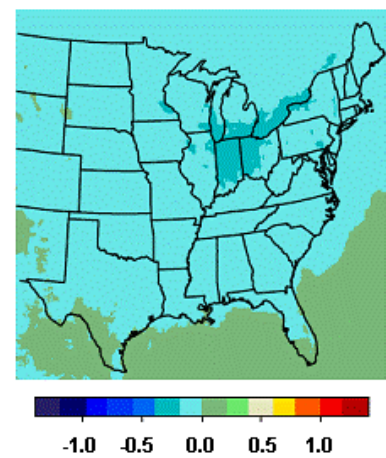

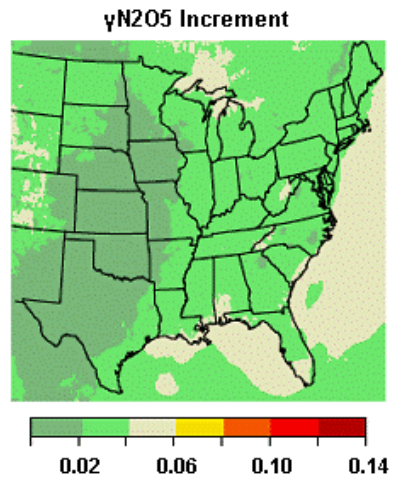

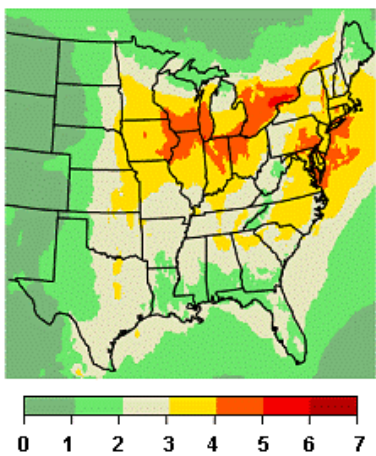

Fig. 1. Top row shows the average nighttime (04:00-09:00,GMT) values of $\gamma_{\mathrm{N}_{2} \mathrm{O}_{5}}$ at the surface layer over the eastern United States during January 2006. (Daytime hours are not included because $\mathrm{N}_{2} \mathrm{O}_{5}$ concentrations are negligible during the day). Bottom row shows the $\mathrm{TNO}_{3}$ concentrations $\left(\mu \mathrm{g} / \mathrm{m}^{3}\right)$ averaged across all hours in January 2006. The first and last columns show model output from the base model and the $\gamma \mathrm{N}_{2} \mathrm{O}_{5}$ Increment. The middle columns show the impact of correcting the error in the base CMAQ aerosol module and of using the new parameterization for the heterogeneous reaction probability.

In January, the $\gamma_{\mathrm{N}_{2} \mathrm{O}_{5}}$ incremental update slightly decreases the average bias in $\mathrm{TNO}_{3}$ values compared to the corrected base model. At 67 CASTNet sites, the normalized median bias in simulated $\mathrm{TNO}_{3}$ concentrations is $16 \%$ in the corrected base model and $12 \%$ in the $\gamma \mathrm{N}_{2} \mathrm{O}_{5}$ Increment. The positive bias in predicted $\mathrm{TNO}_{3}$ concentrations using the updated model simulation is more evident in the Northeast in the winter time. $\mathrm{TNO}_{3}$ concentrations in the summer time are over predicted in all three of the simulations (the normalized median bias for the three increments is $43 \%$ ), suggesting this bias is not sensitive to the change in the $\gamma$ parameterization during warmer months. In the summer simulations, daytime production of $\mathrm{TNO}_{3}$ is very efficient so it compensates for any changes in the night-time production.

\subsection{SOA model enhancements}

Of all of the changes made to the SOA module, the single most notable effect resulted from the updated enthalpies of vaporization $\left(\Delta \mathrm{H}_{\mathrm{vap}}\right)$. This parameter governs the temperature dependence of atmospheric SOA concentrations (Sheehan and Bowman, 2001). Due to its substantial impact, this update has been plotted separately in Figs. 2 and 3. In previous versions, the $\Delta \mathrm{H}_{\text {vap }}$ value for each SOA type was too large $(156 \mathrm{~kJ} / \mathrm{mol})$, causing exaggerated wintertime SOA peaks and erroneous summertime minima (Yu et al., 2007). Reducing $\Delta \mathrm{H}_{\text {vap }}$ to within the $18-40 \mathrm{~kJ} / \mathrm{mol}$ range in $\mathrm{v} 4.7$ results in a large decrease in both anthropogenic and biogenic SOA concentrations during January and August (compare first and second columns of Figs. 2 and 3). In August, that decrease is offset by the addition of new SOA formation pathways described in Sect. 2.2 (compare lower-center and lower-right plots in Figs. 2 and 3). The net effect of updating $\Delta \mathrm{H}_{\mathrm{vap}}$ and adding the new SOA formation pathways leads to higher SOA concentrations in summer than in winter for both anthropogenic and biogenic SOA across the domain (third column of Figs. 2 and 3, respectively). Qualitatively, this seasonal pattern is in better agreement than v4.6 with observational estimates of SOA (Kleindienst et al., 2007; Yu et al., 2007; Lewandowski et al., 2008).

Updates to the SOA module also improve diurnal patterns of the modeled fine-particulate total carbon (TC). Previous simulations tended to overestimate the daily amplitude (i.e., daily max - daily min) of TC concentrations during summer, due to exaggerated nighttime peaks in biogenic SOA (Morris et al., 2006). Figure 4 shows that the median of daily TC amplitudes in $\mathrm{v} 4.7$ decreases across most of the domain relative to the previous model version. In the grid cell overlaying 

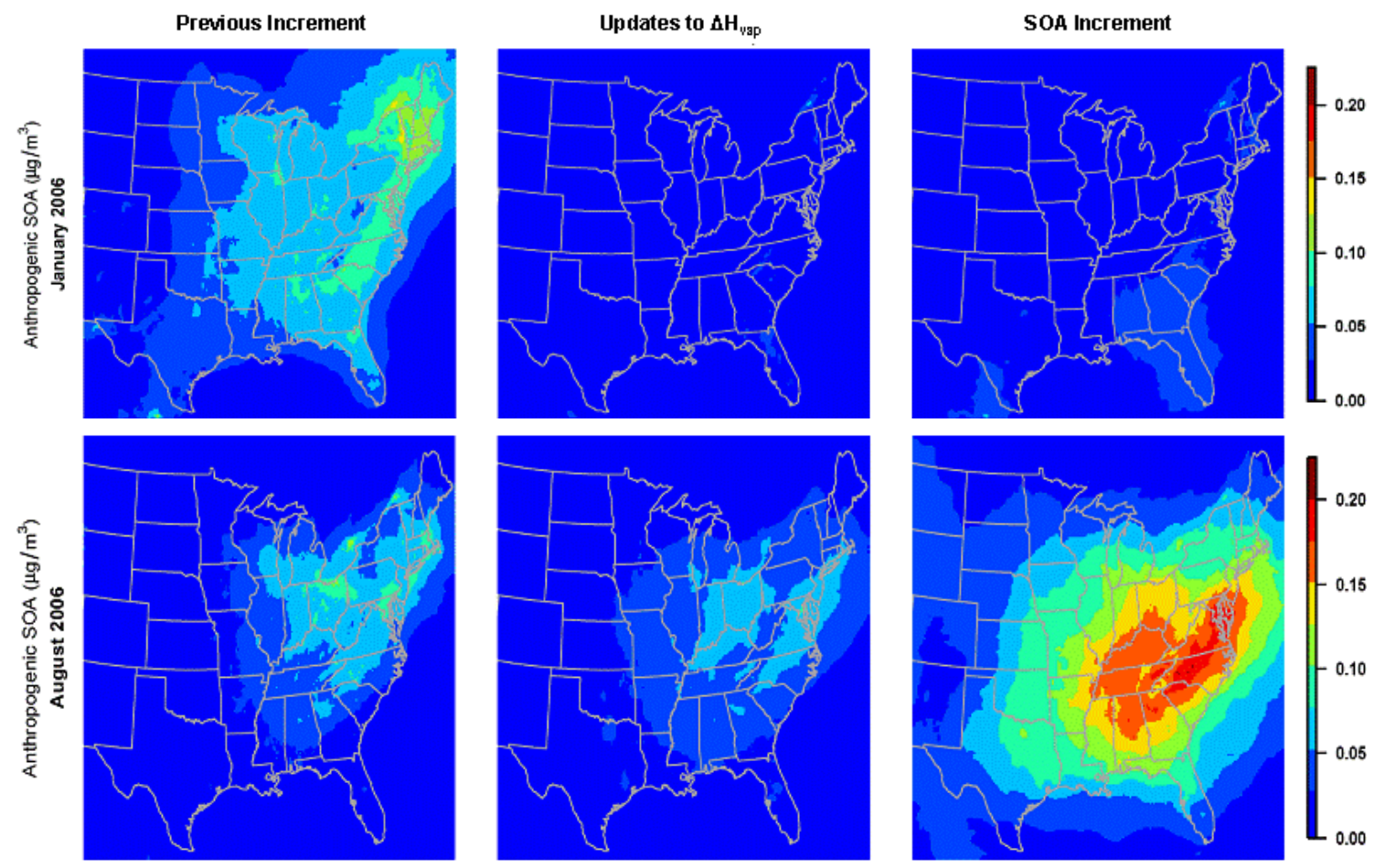

Fig. 2. Monthly average anthropogenic SOA $\left(\mu \mathrm{g} / \mathrm{m}^{3}\right.$ ) for January (top row) and August (bottom row) 2006. The middle column shows the effect of reducing the enthalpies of vaporization $\left(\Delta \mathrm{H}_{\mathrm{vap}}\right)$ compared to the previous increment (left column). The right column shows results from the final SOA module in CMAQ v4.7 described in Sect. 2.2.
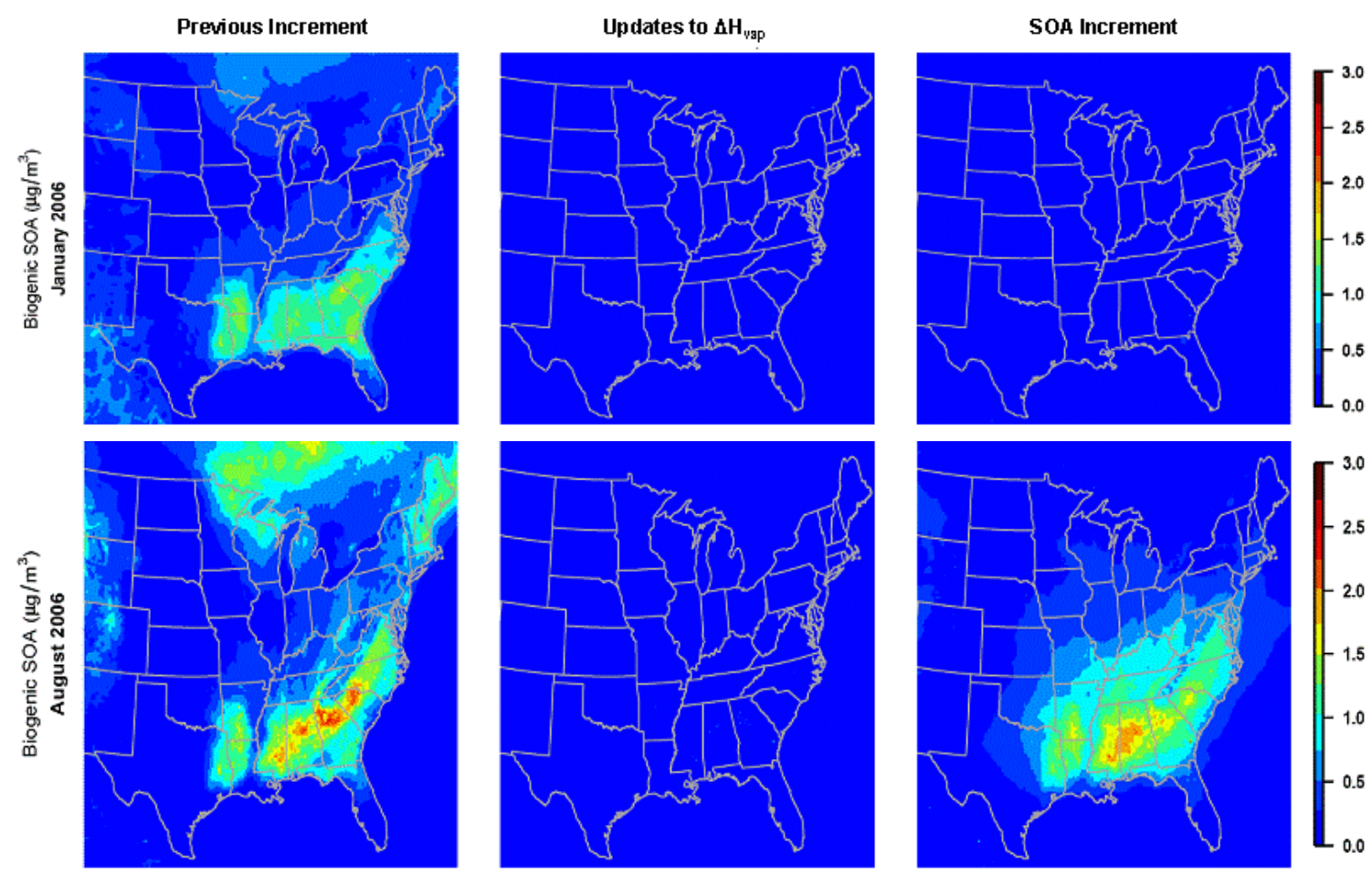

Fig. 3. Monthly average biogenic SOA $\left(\mu \mathrm{g} / \mathrm{m}^{3}\right)$ for January (top row) and August (bottom row) 2006. The middle column shows the effect of reducing the enthalpies of vaporization $\left(\Delta \mathrm{H}_{\mathrm{vap}}\right)$ compared to the previous increment (left column). The right column shows results from the final SOA module described in Sect. 2.2. 


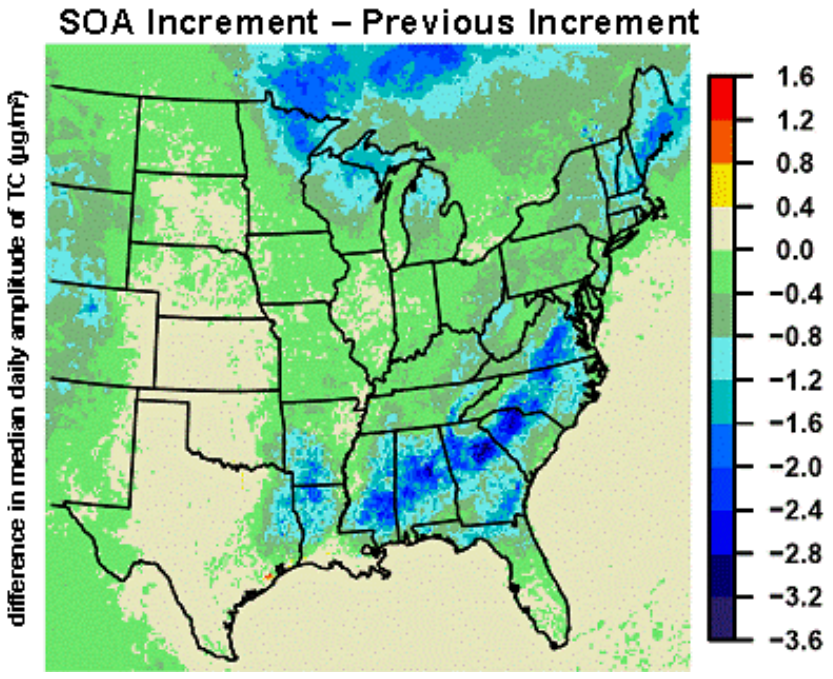

Fig. 4. Difference in the median of daily amplitudes (daily max daily $\min$ ) for TC $\left(\mu \mathrm{g} / \mathrm{m}^{3}\right)$ between the SOA module update and the previous model version for August 2006.

the Duke Forest, NC site, the median daily TC amplitude dropped from $4.3 \mu \mathrm{gC} / \mathrm{m}^{3}$ in the previous model version to $2.5 \mu \mathrm{gC} / \mathrm{m}^{3}$ in the SOA Increment. The latter is consistent with the amplitude of $2.6 \mu \mathrm{gC} / \mathrm{m}^{3}$ observed throughout August 2006 at the same location (Geron, 2009). A similar improvement was noted in Yorkville, GA (modeled TC amplitude also dropped from 4.3 to $2.5 \mu \mathrm{g} / \mathrm{m}^{3}$ ), where observations also indicate a median daily TC amplitude of $2.6 \mu \mathrm{g} / \mathrm{m}^{3}$ (based on 17 days in August 2003 with more than 75\% data completeness; Edgerton et al., 2006).

As noted in Sect. 2.2, regulatory drivers motivated a need to incorporate the most up-to-date treatment of aromatic SOA formation into CMAQ v4.7. The inclusion of NOxdependent yields increased anthropogenic SOA by more than a factor of three in the Southeast during summer (compare lower-left and lower-right plots in Fig. 2), bringing CMAQ results closer to the best-available observational estimates of aromatic SOA in the same region (Kleindienst et al., 2007 measured $0.8 \mu \mathrm{C} / \mathrm{m}^{3}$ on highly-polluted days in July-August 2003). Efforts are underway to evaluate CMAQ v4.7 results directly against tracer-based estimates of precursor-specific SOA at times and locations where such detailed measurements were collected. In the present study, our evaluation of the modeled concentrations of carbonaceous $\mathrm{PM}_{2.5}$ is limited to the bulk measurements that are available at routine monitoring networks: TC, organic carbon (OC), and elemental carbon (EC).

\subsection{Coarse-particle chemistry}

Chemical interactions between coarse particles and gasphase pollutants were not treated in previous versions of CMAQ. The addition of such interactions causes modeled
$\mathrm{PM}_{2.5}$ concentrations to decline in August 2006, as shown in the first row of Fig. 5. Lower modeled concentrations of $\mathrm{PM}_{2.5}$ are largely explained by changes in the distributions of $\mathrm{SO}_{4}^{2-}$ and $\mathrm{NH}_{4}^{+}$across the particle size spectrum, as these species now are allowed to condense on the coarse mode. Shifting mass to the coarse particles also increases the dry deposition of both $\mathrm{SO}_{4}^{2-}$ and reduced nitrogen. During winter, the effects of coarse-particle chemistry on $\mathrm{PM}_{2.5}$ are less pronounced than in summer due to relatively low $\mathrm{SO}_{4}^{2-}$ concentrations.

The new coarse-particle treatment also impacts $\mathrm{NO}_{3}^{-}$predictions during the winter. Over the ocean, coarse-particle $\mathrm{NO}_{3}^{-}$increases at the expense of $\mathrm{HNO}_{3}$ (middle and bottom rows of Fig. 5). Shifting $\mathrm{NO}_{3}^{-}$from the gas phase to coarse particles can affect the dry deposition of nitrogen in coastal ecosystems because the deposition velocity of $\mathrm{HNO}_{3}$ differs from that of coarse-mode $\mathrm{NO}_{3}^{-}$(Pryor and Sørensen, 2000). During summer, a similar effect was found. For further details on these model changes and the impacts in coastal areas, see Kelly et al. (2009).

Observations from nine CASTNet sites near the coast show that model bias in $\mathrm{TNO}_{3}$ decreased both during summer and winter as a result of the updated coarse PM treatment and improved surf-zone emissions (bottom row of Fig. 6). These improvements are driven by decreases in modeled $\mathrm{HNO}_{3}$ concentrations. Four SEARCH monitors along the Gulf Coast provide observations of both coarse and fine particle $\mathrm{NO}_{3}^{-}$. Prior to CMAQv4.7, the formation of coarse mode $\mathrm{NO}_{3}^{-}$was not treated (i.e., model predictions were $0.0 \mu \mathrm{g} / \mathrm{m}^{3}$ ), leading to the underestimation as shown in the top row of Fig. 6. The revised model improves the predicted concentrations for coarse particles substantially, without degrading the performance for fine particle $\mathrm{NO}_{3}^{-}$at these locations.

\subsection{Cloud model improvements}

Revisions to the cloud model produced the largest change in $\mathrm{SO}_{4}^{2-}$ predictions. In general, modeled $\mathrm{SO}_{4}^{2-}$ concentrations increase for the Cloud Increment in both January and August 2006 as shown in Fig. 7. The increase in concentrations in January is due to the correction of the vertical allocation of the precipitation flux in the resolved cloud model discussed in Sect. 2.3. Prior to this change, more $\mathrm{SO}_{4}^{2-}$ was removed by wet deposition from layer 1 . Concentrations of other PM species show a similar relative increase in the January simulation with the changes in the cloud model. The August simulation shows a more significant increase in $\mathrm{SO}_{4}^{2-}$ concentrations (ranging from 0.25 to $1.25 \mu \mathrm{g} / \mathrm{m}^{3}$ throughout much of the domain) because of changes made to the convective cloud model and the increased convective cloud activity during the summer.

Spatial plots of the monthly total $\mathrm{SO}_{4}^{2-}$ wet deposition (Fig. 8) show that the cloud model revisions produce a slight decrease in $\mathrm{SO}_{4}^{2-}$ wet deposition in both January and August. 

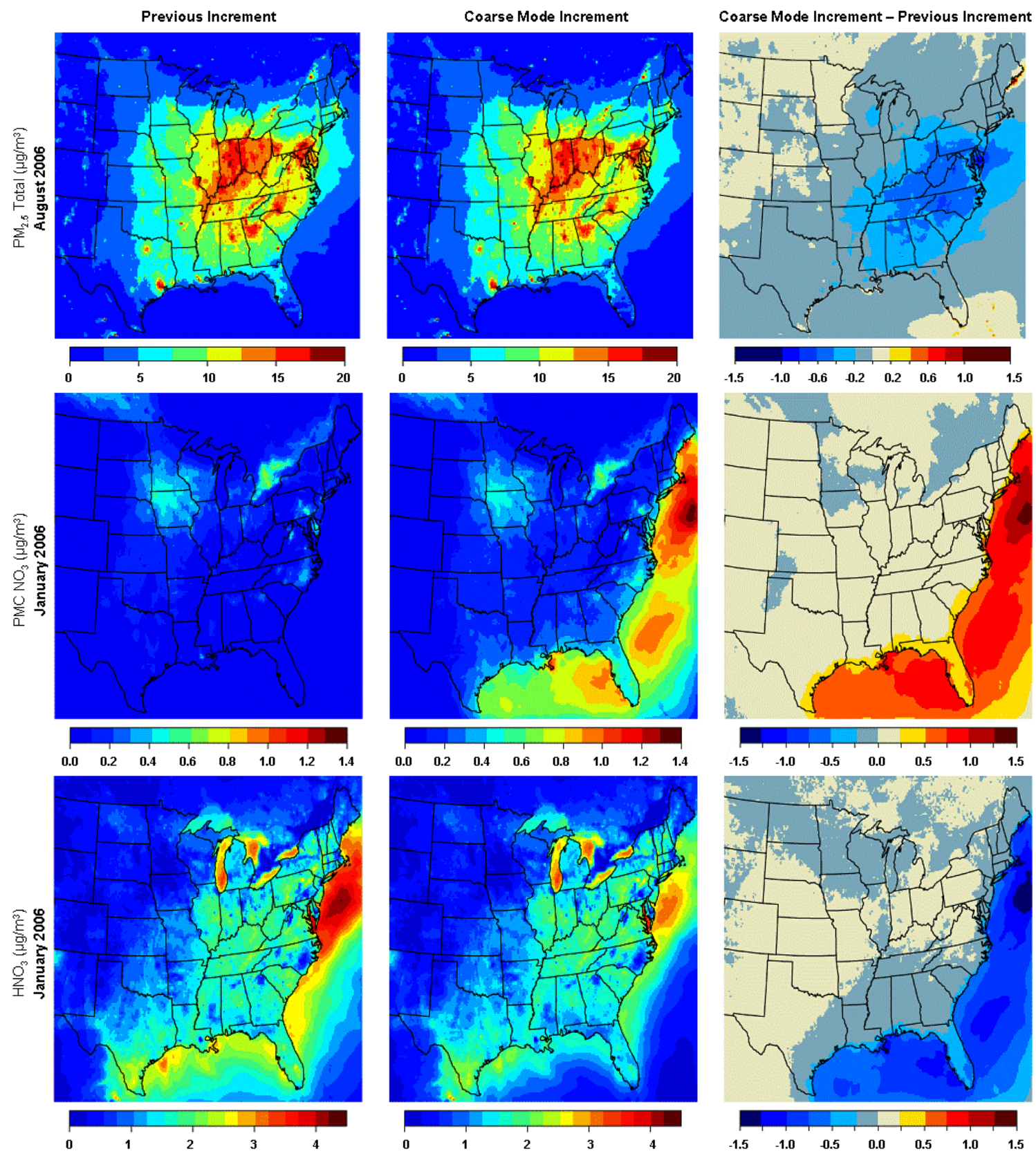

Fig. 5. Monthly average concentrations $\left(\mu \mathrm{g} / \mathrm{m}^{3}\right)$ of $\mathrm{PM}_{2.5}$ in August 2006 (top row), and coarse-particle $\mathrm{NO}_{3}^{-}$(middle row) and gas-phase $\mathrm{HNO}_{3}$ (bottom row) in January 2006. Results are shown from the previous model increment (left column), the revised model (middle column) and their difference (right column).

The difference plot for January is much smoother than for August, reflecting the different cloud types and precipitation for each season (e.g., grid-resolved clouds in the winter and sub-grid convective clouds in the summer).

From an evaluation perspective, these changes made modest improvements to $\mathrm{SO}_{4}^{2-}$ aerosol concentrations and smaller changes for wet deposition $\mathrm{SO}_{4}^{2-}$. In January, the normalized median bias at $174 \mathrm{CSN}$ sites is $-13.2 \%$ in the
Coarse Mode Increment compared to $-4.1 \%$ in the Cloud Increment. In August, the normalized median bias improves from $-6.0 \%$ to $0.8 \%$. A similar decrease in bias is also observed at the IMPROVE monitoring sites. The improvement in model performance for $\mathrm{SO}_{4}^{2-}$ wet deposition at NADP sites is negligible. The normalized median bias decreases by $4.2 \%$ in January and only $0.2 \%$ in August. 
SEARCH Sites

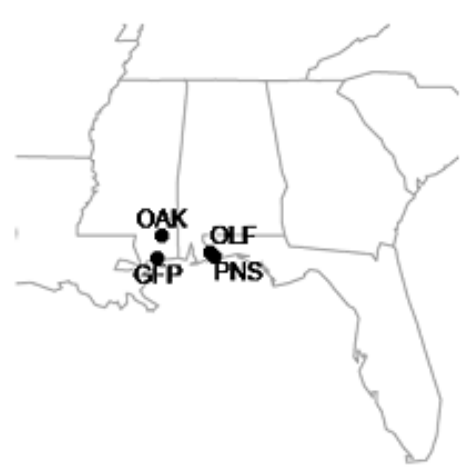

CASTNet Sites

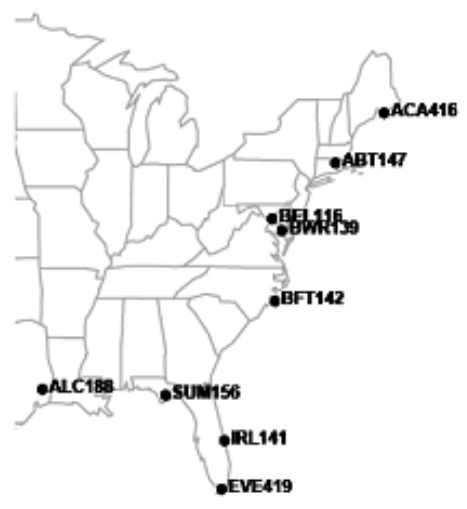

January 2006
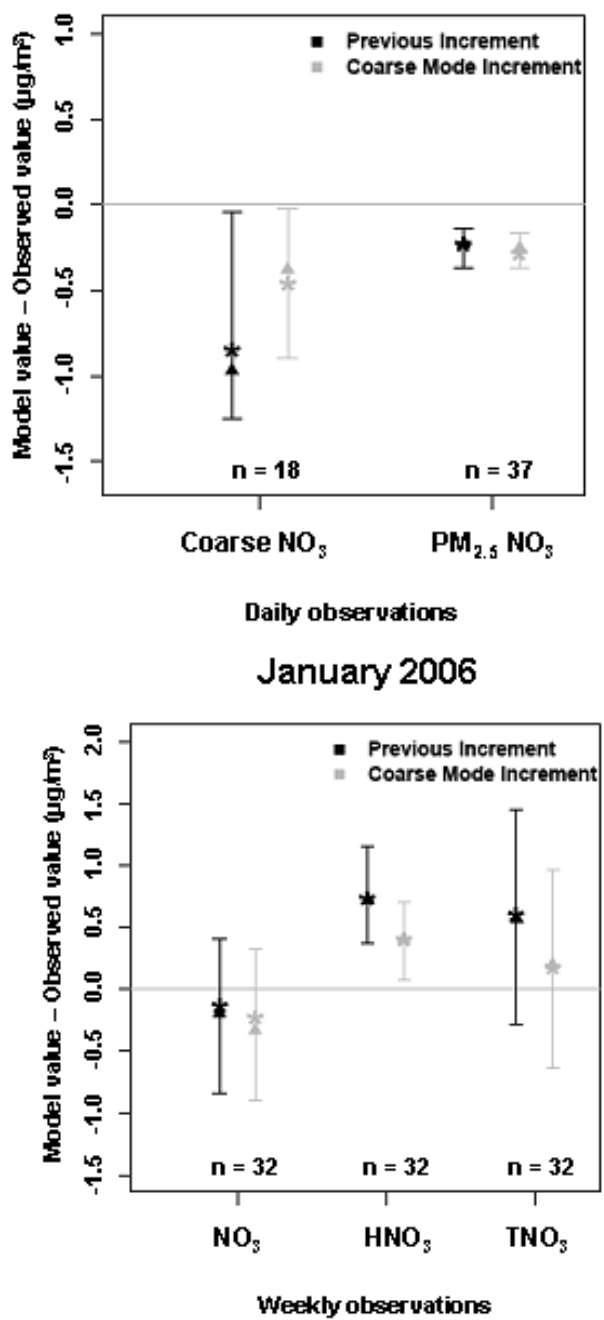

August 2006

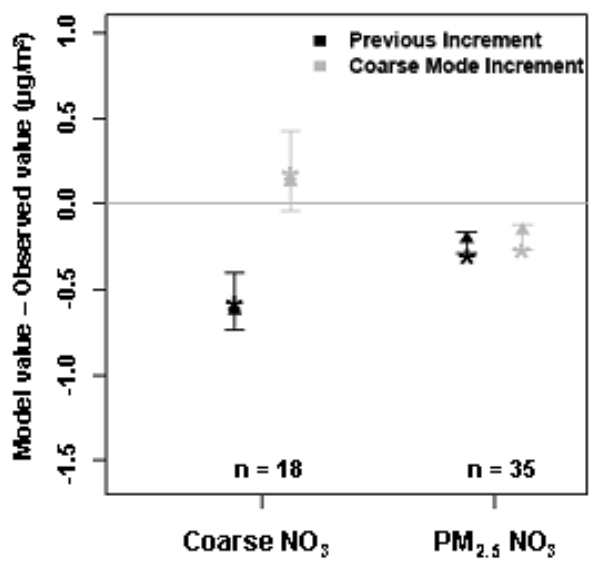

Daily observations

August 2006

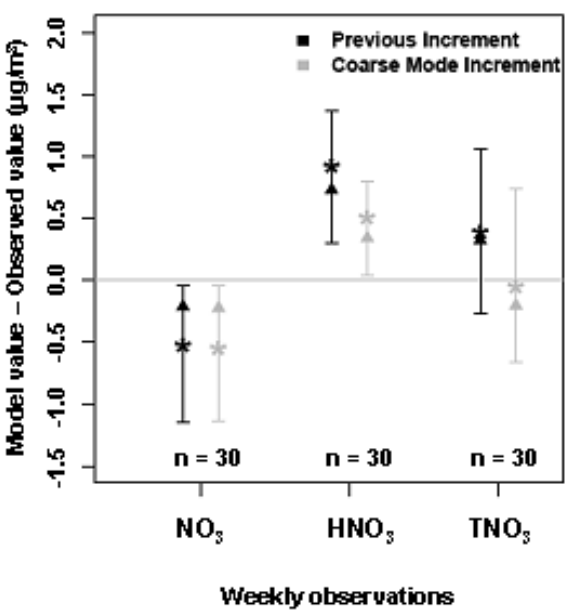

Fig. 6. Mean (star), median (triangle), and inter-quartile ranges of model bias (model value - observed value) for multiple species measured at 9 coastal CASTNet sites and 4 SEARCH sites. The number of model/observation pairs for each species is shown above the $\mathrm{x}$-axis.

\subsection{In-line photolysis research option}

The in-line photolysis module calculated lower decreases monthly average photolysis rates at the surface layer compared to the values interpolated from JPROC. The differences are most pronounced in areas of high elevation as shown in the difference plots in Fig. 9 for the $\mathrm{NO}_{2}$ and $\mathrm{O}_{3} \rightarrow \mathrm{O}\left({ }^{1} \mathrm{D}\right)$ photolysis reactions. Photolysis rates increase with height because there is less absorption of incoming direct radiation and more indirect radiation from below (atmospheric scattering from below). The table interpolation method calculates higher photolysis rates in high elevation areas because vertical interpolation of these rates to the grid cell terrain height overestimates the indirect radiation from below. The in-line module performs radiative transfer calculations for every grid cell, directly accounting for the terrain heights. Geographic differences are evident in both panels of Fig. 9, however, differences in the $\mathrm{O}_{3} \rightarrow \mathrm{O}\left({ }^{1} \mathrm{D}\right)$ photolysis rates are much larger than for $\mathrm{NO}_{2}$. In addition to the elevation affects noted above, the $\mathrm{O}_{3} \rightarrow \mathrm{O}\left({ }^{1} \mathrm{D}\right)$ photolysis rates are also influenced by the stratospheric ozone column values used in each model. As noted by Binkowski et al. (2007), the stratospheric ozone column amount may be overestimated with the in-line photolysis module because the method (Van Heuklon, 1979) used to compute these values does not account for stratospheric ozone depletion that occurred during the last 30 years. Satellite measurements of $\mathrm{O}_{3}$ column (http://toms.gsfc.nasa.gov/ozone/ozone_v8.html) will replace this method in future model releases.

These differences in photolysis rates have multiple impacts on model chemistry. Monthly average $\mathrm{SO}_{4}^{2-}$ decreases by 0.1 to $0.8 \mu \mathrm{g} / \mathrm{m}^{3}$ over the eastern part of the domain due to 

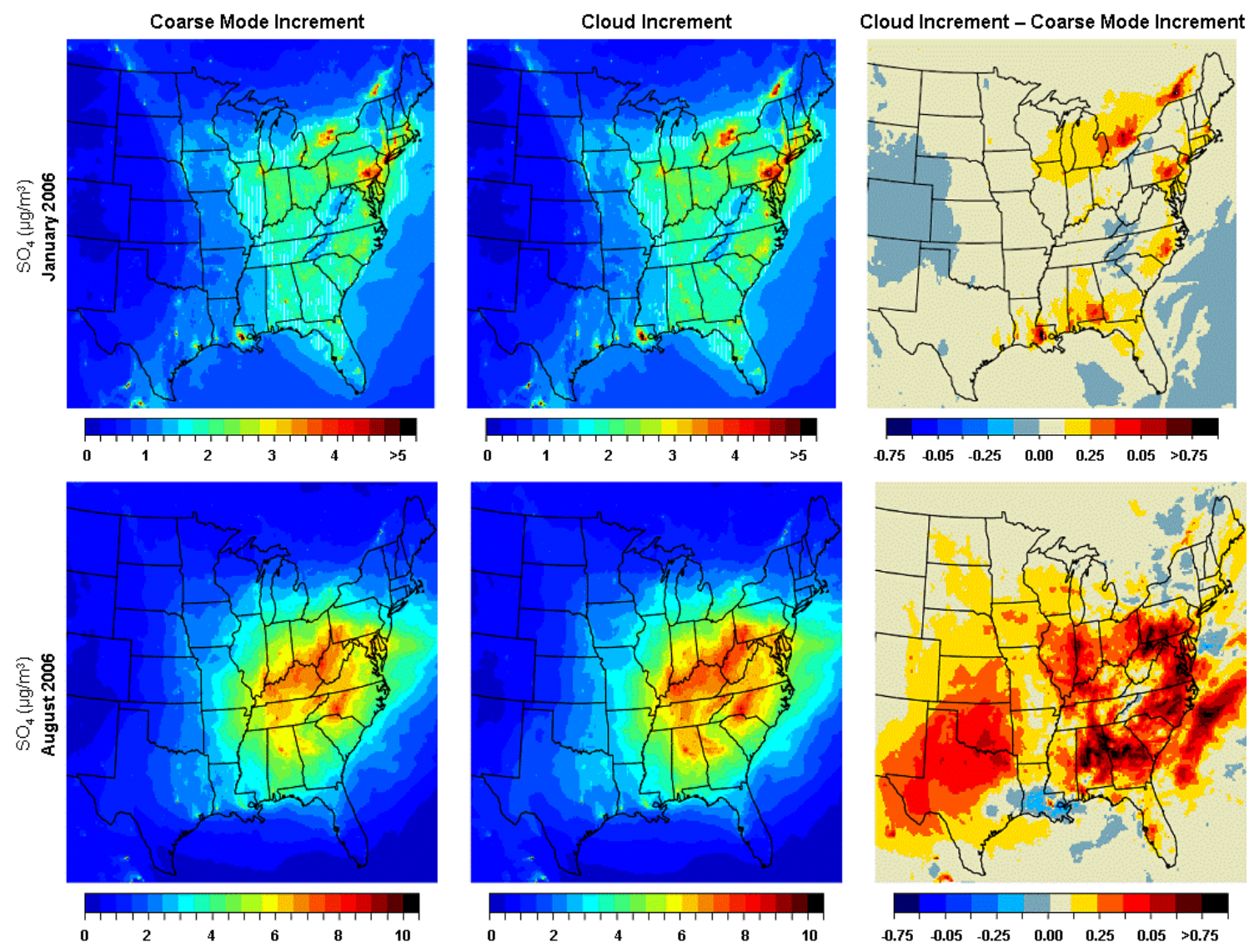

Fig. 7. Monthly average $\mathrm{SO}_{4}^{2-}$ concentrations $\left(\mu \mathrm{g} / \mathrm{m}^{3}\right.$ ) for January (top row) and August (bottom row) 2006 for the previous model (left column), revised model (middle column) and their difference (right column).

slower oxidation of $\mathrm{SO}_{2}$ to $\mathrm{SO}_{4}^{2-}$. Slower oxidation and removal of VOC leads to increases of VOC by $1-7 \%$ throughout most of the domain. Decreased photolysis rates lead to less $\mathrm{O}_{3}$ production in most of the eastern United States. Along the southern coast, the monthly average of the daily maximum 8-h average $\mathrm{O}_{3}$ increased by $<1 \mathrm{ppb}$. Across the rest of the domain, the new calculation of the photolysis rates tends to decrease the daily maximum 8 -h average $\mathrm{O}_{3}$ by $0.3-$ $2.2 \mathrm{pbb}(0.4-3.7 \%)$ (Nolte et al., 2008c).

\section{Evaluation of CMAQv4.7}

The released model version, CMAQv4.7, includes the changes described above as well as other miscellaneous code updates documented in Sect. 2 and in the release notes available from http://www.cmaq-model.org. Model performance under default settings is evaluated for the set of pollutants of primary interest for policy applications: total $\mathrm{PM}_{2.5}$ mass, $\mathrm{PM}_{2.5}$ species, $\mathrm{O}_{3}$, and wet deposition of $\mathrm{SO}_{4}^{2-}, \mathrm{NO}_{3}^{-}$and $\mathrm{NH}_{4}^{+}$. The impacts of optional model configurations, e.g., the two new options for calculating photolysis rate constants and the in-line processing option are not addressed in this section.

\section{$5.1 \quad \mathbf{P M}_{2.5}$}

The net impact of all of the scientific updates on model performance for total $\mathrm{PM}_{2.5}$ mass and its components is shown in Fig. 10. (Additional performance statistics for the bias and error of these species at IMPROVE, CSN and CASTNet sites are provided in Tables 3 and 4.) In January at the rural IMPROVE sites, there is a slight improvement in the median bias for total $\mathrm{PM}_{2.5}$ mass $\left(+0.57 \mu \mathrm{g} / \mathrm{m}^{3}\right.$ in the base model versus $+0.40 \mu \mathrm{g} / \mathrm{m}^{3}$ in v4.7). This is mainly a result of the updated $\Delta \mathrm{H}_{\mathrm{vap}}$ values in the SOA module which decrease the OC predictions in winter (see top rows of Figs. 2 and 3).

In January at the urban-orientated CSN sites, the negative median biases in $\mathrm{SO}_{4}^{2-}$ and $\mathrm{NO}_{3}^{-}$predictions and the positive median bias in TC predictions are reduced slightly in v4.7 relative to the base model (see Table 3). Sulfate predictions increase due to the cloud module updates, so the median bias improves from $-0.30 \mu \mathrm{g} / \mathrm{m}^{3}$ in the base model to $-0.13 \mu \mathrm{g} / \mathrm{m}^{3}$ in $\mathrm{v} 4$.7. The new $\gamma_{\mathrm{N}_{2} \mathrm{O}_{5}}$ parameterization and cloud module updates also improve the $\mathrm{NO}_{3}^{-}$median bias slightly, from $-0.10 \mu \mathrm{g} / \mathrm{m}^{3}$ in the base model to $+0.01 \mu \mathrm{g} / \mathrm{m}^{3}$ 

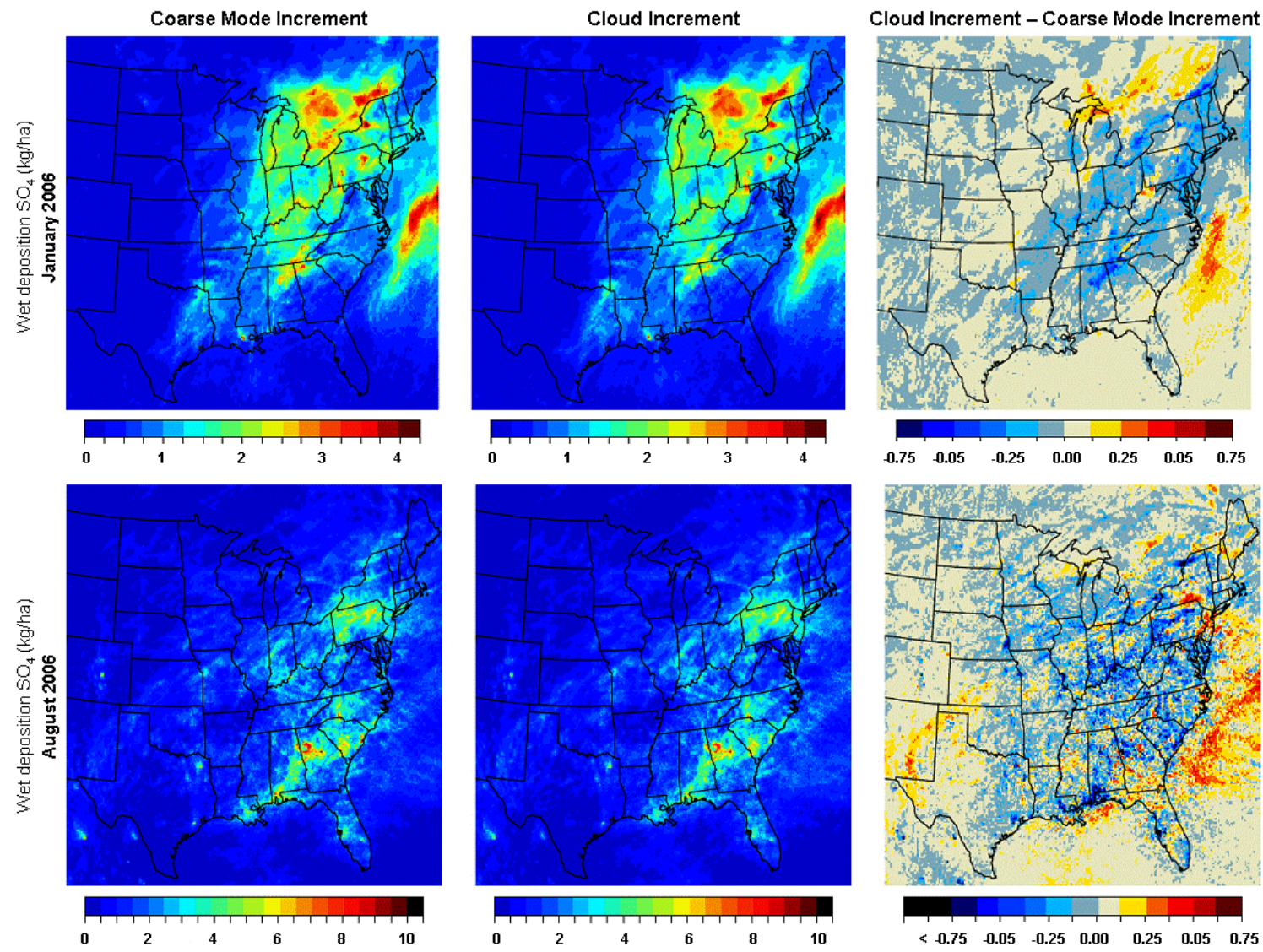

Fig. 8. Monthly total $\mathrm{SO}_{4}^{2-}$ wet deposition (kg/ha) for January (top row) and August (bottom row) 2006 for the previous model (left column), revised model (middle column) and their difference (right column).
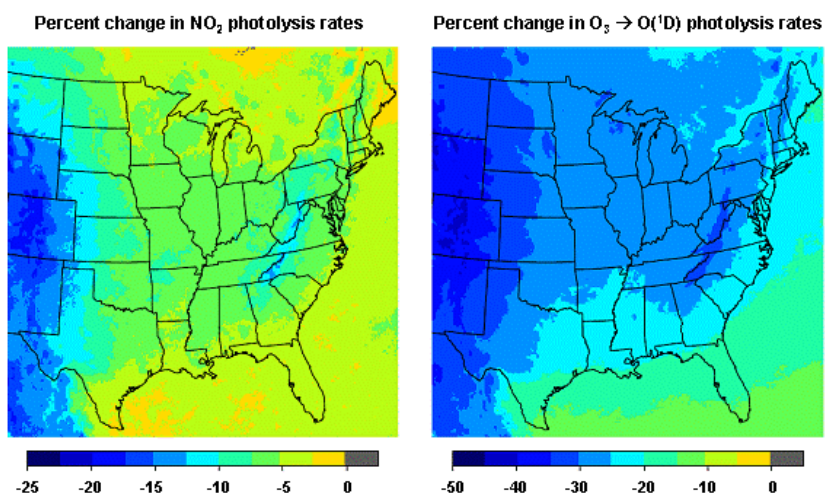

Fig. 9. Percent change in monthly averaged photolysis rates over daytime hours (14:00-24:00 Z) for $\mathrm{NO}_{2}$ (left) and $\mathrm{O}_{3} \rightarrow \mathrm{O}\left({ }^{1} \mathrm{D}\right)$ (right).

in v4.7. Increased CMAQ predictions of both $\mathrm{SO}_{4}^{2-}$ and $\mathrm{NO}_{3}^{-}$lead to a small bias in $\mathrm{NH}_{4}^{+}$of $+0.15 \mu \mathrm{g} / \mathrm{m}^{3}$, but this is acceptable because the measurements of $\mathrm{NH}_{4}^{+}$on denuded nylon filters are believed to have a negative bias (Frank, 2006). In contrast to the inorganic ions, TC predictions de-

crease between the base model and v4.7. This decrease can be attributed to improvements in the SOA module, which slightly mitigate the median bias for TC $\left(+0.43 \mu \mathrm{g} / \mathrm{m}^{3}\right.$ in the base model versus $+0.27 \mu \mathrm{g} / \mathrm{m}^{3}$ in v4.7). The net effect of improving the predictions of $\mathrm{SO}_{4}^{2-}, \mathrm{NO}_{3}^{-}$, and TC in January at the CSN sites is a degradation in model performance for total $\mathrm{PM}_{2.5}$ mass $\left(+1.61 \mu \mathrm{g} / \mathrm{m}^{3}\right.$ in the base model versus $+1.92 \mu \mathrm{g} / \mathrm{m}^{3}$ in $\mathrm{v} 4.7$ ), because we have removed some compensating errors from the predictions of individual $\mathrm{PM}_{2.5}$ components.

However, the improvements in model performance in January for individual constituents are dwarfed by the large overprediction of unspeciated $\mathrm{PM}_{2.5}\left(\mathrm{PM}_{\mathrm{other}}\right)$, which was unaffected by the scientific updates described in this paper (median bias is $+1.9 \mu \mathrm{g} / \mathrm{m}^{3}$ in both the base model and v4.7). As seen in the lower center panel of Fig. 10, the v4.7 model bias for total $\mathrm{PM}_{2.5}$ mass is explained almost entirely by the bias in $\mathrm{PM}_{\mathrm{other}}$. Similar bias in wintertime $\mathrm{PM}_{\text {other }}$ was reported previously by Hogrefe et al. (2007), Appel et al. (2008) and Mathur et al. (2008b). Since this component represents primary emitted fine particulate matter, careful assessment of the emission inventories and their speciation and temporal allocation is warranted in future studies. 
IMPROVE Sites

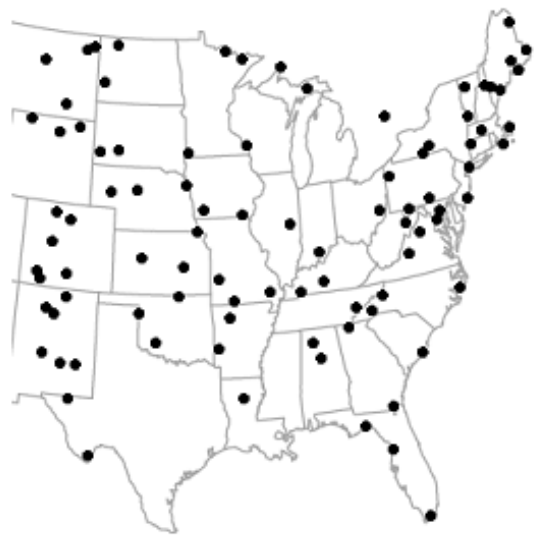

\section{CSN Sites}

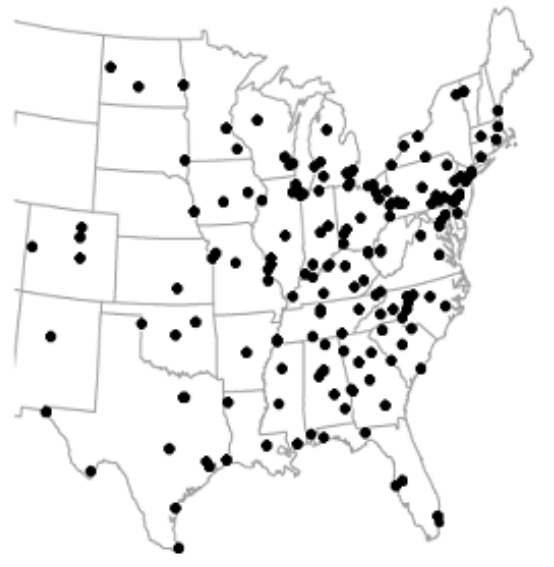

January 2006

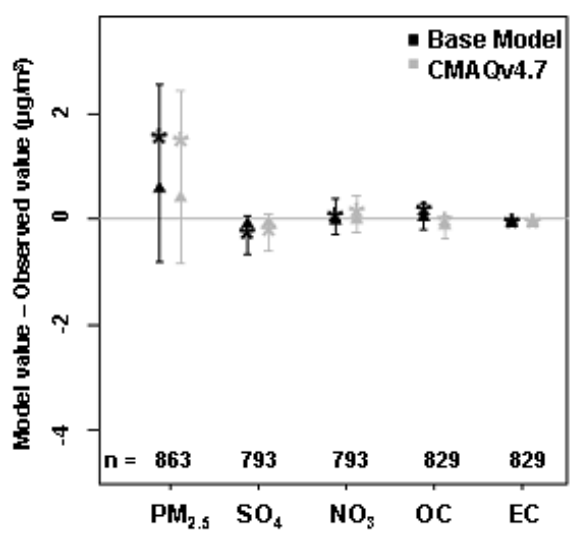

Daily observations

January 2006

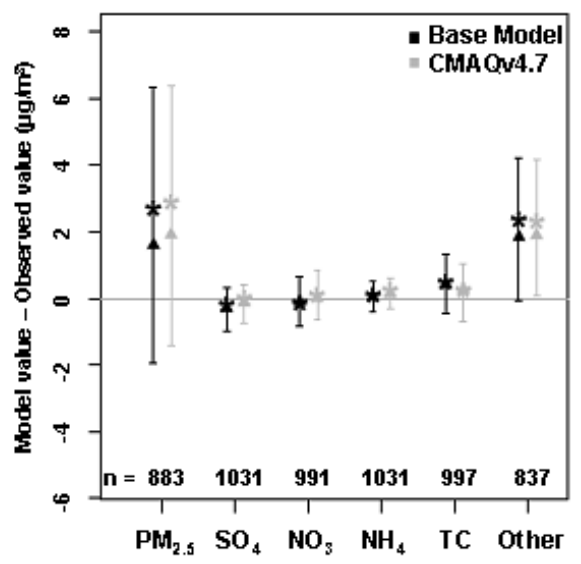

Daily observations
August 2006

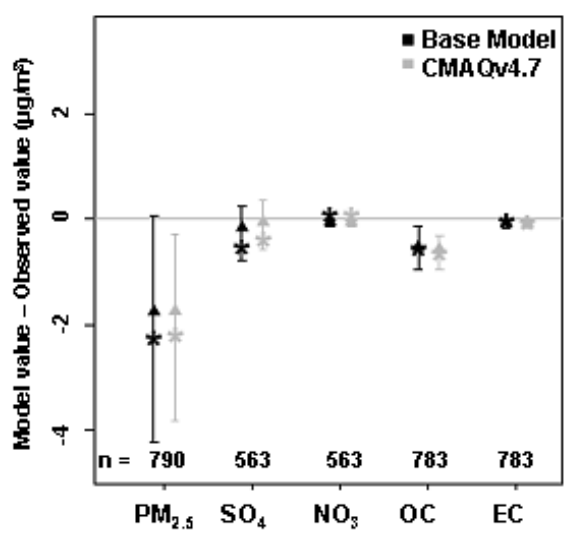

Daily observations

August 2006

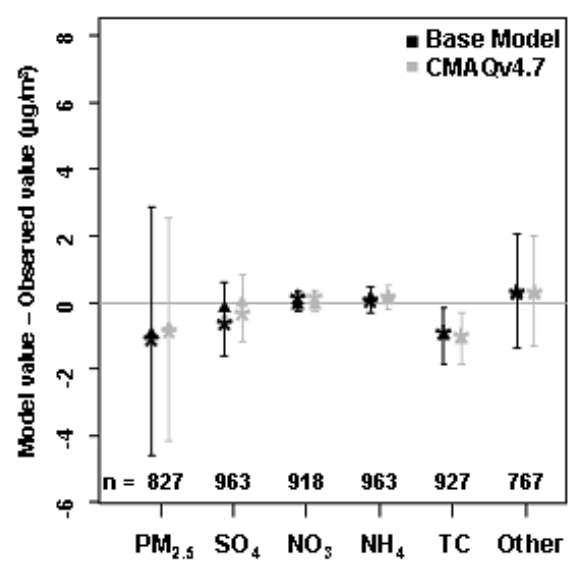

Daily observations

Fig. 10. Mean (star), median (triangle), and inter-quartile ranges of model bias (model value - observed value) for multiple fine-particle species measured at IMPROVE and CSN sites in the $12 \mathrm{~km}$ domain. IMPROVE and CSN observations are daily averages. The number of model/observation pairs for each species is shown above the $\mathrm{x}$-axis.
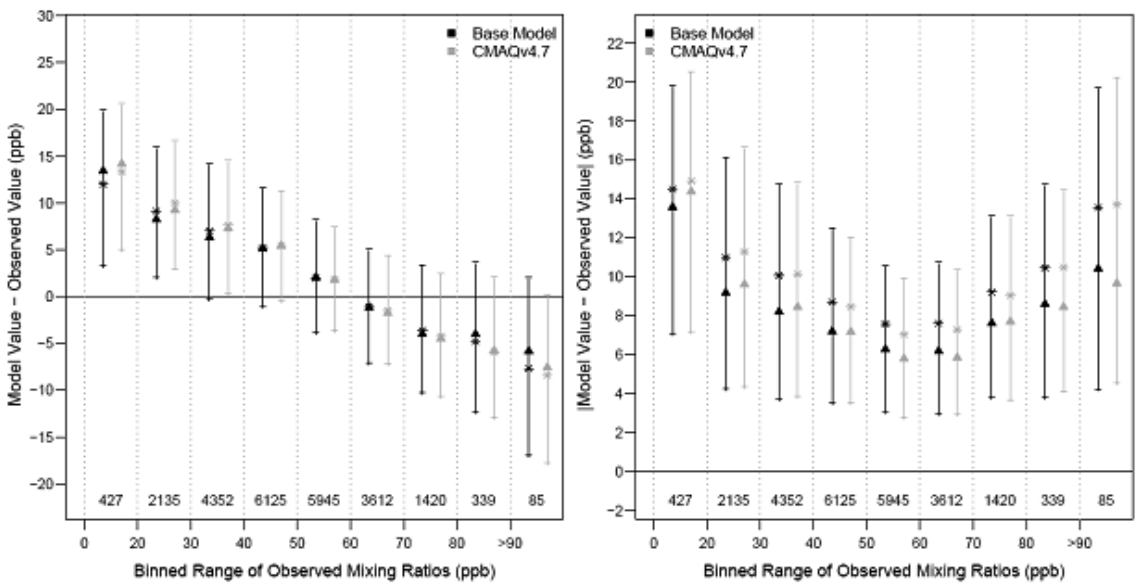

Fig. 11. Mean (star), median (triangle), and inter-quartile ranges of model bias (left) and absolute model bias (right) binned by observed ozone mixing ratios for August 2006. The number of model/observation pairs for each bin is shown above the $\mathrm{x}$-axis. 

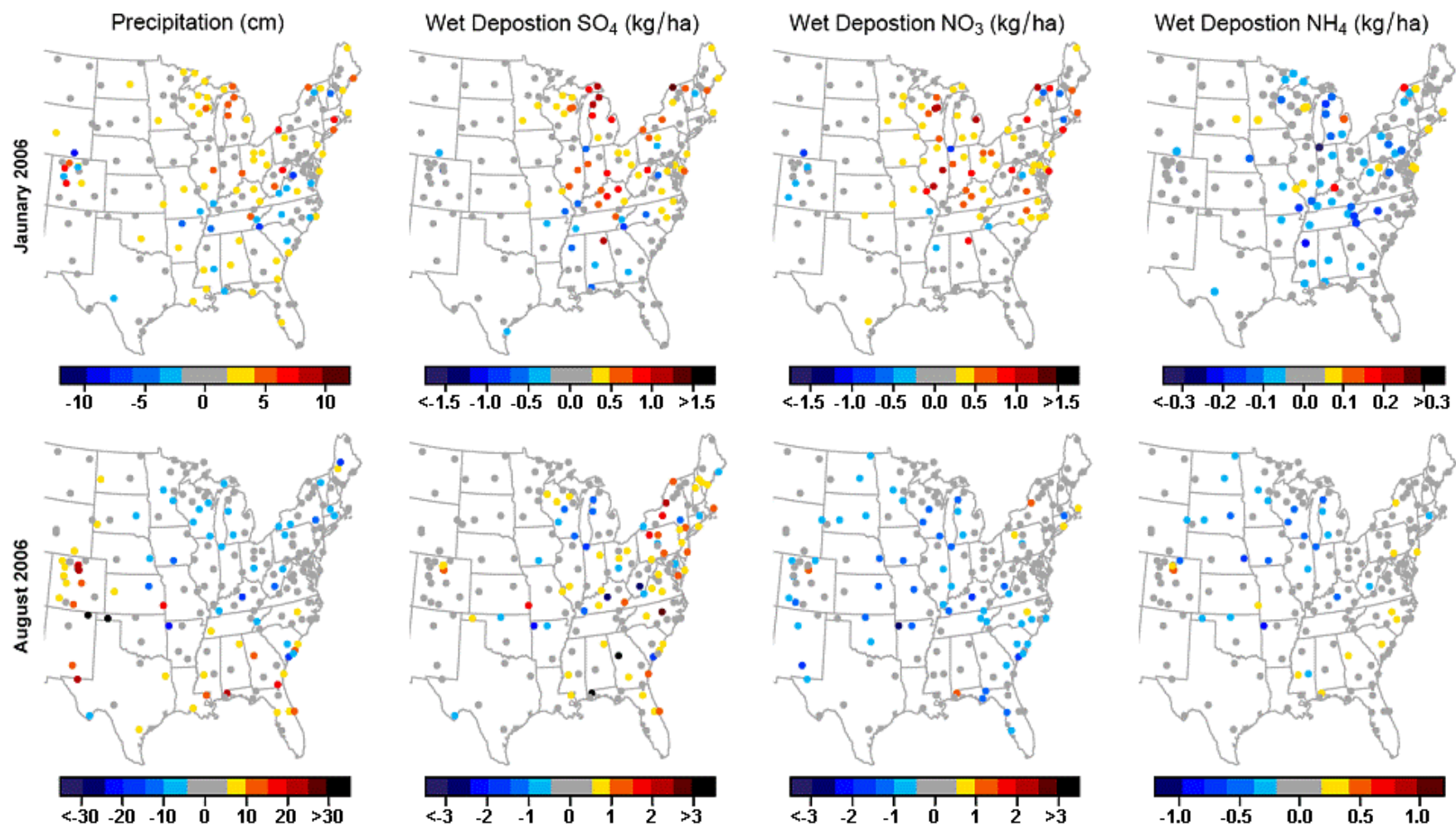

Fig. 12. Difference in monthly total precipitation (cm), wet deposition $\mathrm{SO}_{4}^{2-}(\mathrm{kg} / \mathrm{ha})$, wet deposition $\mathrm{NO}_{3}^{-}(\mathrm{kg} / \mathrm{ha})$, and wet deposition $\mathrm{NH}_{4}^{+}$ (kg/ha) between the CMAQv4.7 model values and the NADP observations for January (top row) and August (bottom row). January totals are for 3-31 January; August totals are for 1-29 August 2006.

Table 2. Definition of statistical metrics used to compare observed and simulated $\mathrm{O}_{3}$, aerosol species and wet deposition species.

\begin{tabular}{ll}
\hline Metric & Definition \\
\hline Observed Concentration & $C_{\mathrm{O}}$ \\
Modeled Concentration & $C_{\mathrm{m}}$ \\
Median Bias & $\mathrm{MdnB}=$ median $\left(C_{\mathrm{M}}-C_{\mathrm{O}}\right)_{\mathrm{N}}$ \\
Median Error & $\mathrm{MdnE}=$ median $\left|C_{\mathrm{M}}-C_{\mathrm{O}}\right|_{\mathrm{N}}$ \\
Normalized Median Bias & $\mathrm{NMdnB}=\frac{\operatorname{median}\left(C_{\mathrm{M}}-C_{\mathrm{O}}\right)_{\mathrm{N}}}{\operatorname{median}\left(C_{\mathrm{O}}\right)_{\mathrm{N}}} \cdot 100 \%$ \\
Normalized Median Error & $\mathrm{NMdnE}=\frac{\operatorname{median}\left|C_{\mathrm{M}}-C_{\mathrm{O}}\right|_{\mathrm{N}}}{\operatorname{median}\left(C_{\mathrm{O}}\right)_{\mathrm{N}}} \cdot 100 \%$ \\
\hline
\end{tabular}

In August at the IMPROVE sites, there is very little change in the median bias between the base model and v4.7 for total $\mathrm{PM}_{2.5}$ mass. Although $\mathrm{SO}_{4}^{2-}$ underpredictions are reduced by a factor of three at these sites due to the cloud module updates in v4.7, much of that improvement is offset by a small degradation in the OC predictions (see Table 4). At the CSN sites, the $\mathrm{PM}_{2.5}$ bias is improved due to the increase in $\mathrm{SO}_{4}^{2-}$. However $\mathrm{PM}_{2.5}$ is still underpredicted (median bias $=-0.78 \mu \mathrm{g} / \mathrm{m}^{3}$ ) and this bias in August is dominated by the underprediction in TC concentrations (median bias $=-1.11 \mu \mathrm{g} / \mathrm{m}^{3}$ ). Future efforts to improve the summertime $\mathrm{PM}_{2.5}$ underpredictions at both IMPROVE and CSN sites will require improvements to the treatment of organic aerosol in CMAQ (see Sect. 6).

\subsection{Ozone}

Appel et al. (2009) discuss how the change from MM5 to WRF meteorological input fields had a significant impact on $\mathrm{O}_{3}$, increasing the modeled monthly-average mixing ratios in August by up to $10 \mathrm{ppb}$ along the Gulf of Mexico. In contrast, updates to the CMAQ chemistry and cloud modules resulted in a much smaller change in the monthly-average simulated values of daily maximum $8-\mathrm{h} \mathrm{O}_{3}(< \pm 3 \mathrm{ppb})$. Model biases noted in previously released versions are still present. Specifically, relative to the AQS observations, low $\mathrm{O}_{3}$ mixing ratios are overpredicted and higher $\mathrm{O}_{3}$ mixing ratios tend to be underpredicted as shown in the binned boxplots in Fig. 11. The bias and absolute bias values are slightly worse in the upper and lower tail of the observed $\mathrm{O}_{3}$ distribution compared to the base model.

Updates to HONO chemistry described in Sect. 2.4 had a smaller impact on $\mathrm{O}_{3}$ compared to other changes in the model. Relative to the base model, slightly greater underpredictions at the high mixing ratios $(>70 \mathrm{ppb})$ are noted in CMAQv4.7. This is most likely due to changes implemented 
Table 3. RMSE, NMdnB, NMdnE, MdnB and $\mathrm{MdnE}$ for $\mathrm{O}_{3}(\mathrm{ppb})$, fine-particulate mass and species $\left(\mu \mathrm{g} / \mathrm{m}^{3}\right)$, precipitation $(\mathrm{cm})$ and wet deposition species $(\mathrm{kg} / \mathrm{ha})$ for January 2006. These metrics are defined in Table 2.

\begin{tabular}{|c|c|c|c|c|c|c|c|c|c|c|c|}
\hline \multirow[t]{2}{*}{ Species } & \multirow[t]{2}{*}{ Network } & \multirow[t]{2}{*}{ \# of Obs } & \multirow[t]{2}{*}{ Mdn of Obs } & \multicolumn{2}{|c|}{ NMdnB (\%) } & \multicolumn{2}{|c|}{$\operatorname{NMdnE}(\%)$} & \multicolumn{2}{|c|}{$\mathrm{MdnB}$} & \multicolumn{2}{|c|}{ MdnE } \\
\hline & & & & Base & $\mathrm{v} 4.7$ & Base & $\mathrm{v} 4.7$ & Base & v4.7 & Base & v4.7 \\
\hline $\mathrm{O}_{3}(8-\mathrm{h} \mathrm{Max})$ & AQS & 10534 & 32.5 & 3.4 & 3.9 & 13.3 & 13.2 & 1.12 & 1.27 & 4.33 & 4.29 \\
\hline \multirow{3}{*}{$\mathrm{SO}_{4}^{2-}$} & IMPROVE & 793 & 1.17 & -8.4 & -5.9 & 27.4 & 26.5 & -0.10 & -0.07 & .32 & .31 \\
\hline & $\mathrm{CSN}$ & 1031 & 2.21 & -13.6 & -5.9 & 31.5 & 27.9 & -0.30 & -0.13 & 0.70 & 0.62 \\
\hline & CASTNet & 247 & 1.99 & -20.4 & -16.0 & 21.9 & 21.2 & -0.41 & -0.32 & 0.44 & 0.42 \\
\hline \multirow{2}{*}{$\mathrm{NO}_{3}^{-}$} & IMPROVE & 793 & 0.39 & -8.4 & -4.6 & 86.5 & 82.1 & -0.03 & -0.02 & 0.34 & 0.32 \\
\hline & $\mathrm{CSN}$ & 991 & 1.42 & -7.1 & 0.8 & 51.2 & 49.9 & -0.10 & 0.01 & 0.73 & 0.71 \\
\hline $\mathrm{TNO}_{3}$ & CASTNet & 247 & 2.27 & 3.5 & 19.5 & 18.3 & 25.8 & 0.08 & 0.44 & 0.42 & 0.59 \\
\hline \multirow{2}{*}{$\mathrm{NH}_{4}^{+}$} & CSN & 1031 & 1.09 & 4.6 & 14.1 & 43.2 & 42.6 & 0.05 & 0.15 & 0.47 & 0.46 \\
\hline & CASTNet & 247 & 0.69 & 7.3 & 13.4 & 20.7 & 23.6 & 0.05 & 0.09 & 0.14 & 0.16 \\
\hline $\mathrm{OC}$ & IMPROVE & 829 & 0.65 & 4.5 & -19.8 & 39.0 & 43.6 & 0.03 & -0.13 & 0.25 & 0.28 \\
\hline EC & IMPROVE & 829 & 0.20 & -25.7 & -24.5 & 40.3 & 39.9 & -0.05 & -0.05 & 0.08 & 0.08 \\
\hline \multirow{2}{*}{ TC } & IMPROVE & 829 & 0.85 & -1.5 & -21.1 & 38.2 & 41.9 & -0.01 & -0.18 & 0.33 & 0.36 \\
\hline & $\mathrm{CSN}$ & 997 & 1.89 & 22.6 & 14.3 & 53.4 & 48.7 & 0.43 & 0.27 & 1.01 & 0.92 \\
\hline $\mathrm{PM}_{\text {other }}$ & $\mathrm{CSN}$ & 837 & 2.37 & 77.7 & 80.1 & 96.0 & 95.6 & 1.85 & 1.90 & 2.27 & 2.26 \\
\hline \multirow{2}{*}{$\mathrm{PM}_{2.5}$} & IMPROVE & 863 & 4.16 & 13.8 & 9.5 & 40.3 & 39.7 & 0.57 & 0.40 & 1.68 & 1.65 \\
\hline & $\mathrm{CSN}$ & 883 & 10.00 & 16.05 & 19.1 & 41.3 & 39.1 & 1.61 & 1.91 & 4.13 & 3.91 \\
\hline Precipitation & \multirow{4}{*}{ NADP } & 181 & 5.51 & 18.7 & & 35.3 & & 1.03 & & 1.94 & \\
\hline WetD Sulf. & & 176 & 0.54 & 8.7 & 10.9 & 27.9 & 29.7 & 0.05 & 0.06 & 0.15 & 0.16 \\
\hline WetD Amm. & & 176 & 0.09 & -13.1 & -14.3 & 42.8 & 40.1 & -0.01 & -0.01 & 0.04 & 0.04 \\
\hline WetD Nitr. & & 176 & 0.47 & 32.2 & 34.9 & 51.9 & 49.1 & 0.15 & 0.16 & 0.24 & 0.23 \\
\hline
\end{tabular}

in the sub-grid cloud model. The occurrence of NP clouds increased during the afternoon hours, venting more pollutants from the boundary layer to the free troposphere. Across the entire range of $\mathrm{O}_{3}$ mixing ratios, the performance statistics for the bias and error of CMAQv4.7 predictions at these sites are very similar to the metrics for the base model as shown in Tables 3 and 4. Possible sources of persistent errors in $\mathrm{O}_{3}$ prediction are discussed in Sect. 6.

\subsection{Wet deposition}

Atmospheric deposition is an important sink process and its representation can impact simulated tropospheric pollutant budgets. As discussed in Sect. 4.4, changes to the resolved cloud model tend to decrease monthly $\mathrm{SO}_{4}^{2-}$ wet deposition. This decrease is counteracted, however, by an increase in wet deposition of $\mathrm{SO}_{4}^{2-}$ due to the changes in coarse particle treatment (i.e., the increase in surf-zone emissions and the addition of gas-to-particle mass transfer for coarse particles). The impact of all of the model changes is a slight increase in the model bias for $\mathrm{SO}_{4}^{2-}$ wet deposition in January and August. Changes in $\mathrm{NO}_{3}^{-}$and $\mathrm{NH}_{4}^{+}$wet deposition are also very small in both months. (Performance statistics for model predicted values at NADP sites are given in Tables 3 and 4.) Nitrate wet deposition is overestimated in the winter (median bias $=+0.16 \mathrm{~kg} / \mathrm{ha}$ ) and underestimated in the summer (median bias $=-0.22 \mathrm{~kg} / \mathrm{ha}$ ) compared to observations The median bias in $\mathrm{SO}_{4}^{2-}$ wet deposition is positive but relatively small $(+.06 \mathrm{~kg} / \mathrm{ha}$ in January and $+.10 \mathrm{~kg} / \mathrm{ha}$ in August). There is also a large degree of error associated with all three wet deposition species in both seasons (normalized median error ranges from $30-49 \%$ ).

Figure 12 shows the model bias (model value - observed value) in monthly total precipitation and $\mathrm{SO}_{4}^{2-}, \mathrm{NO}_{3}^{-}$and $\mathrm{NH}_{4}^{+}$wet deposition. Modeled wet deposition is a function of the volume of predicted precipitation within a grid cell and the pollutant concentrations dissolved in the precipitation or scavenged from the atmosphere during precipitation events. As a result, errors in modeled precipitation can have a large impact on wet deposition predictions. The positive bias in $\mathrm{SO}_{4}^{2-}$ wet deposition during August may also be a result of 
Table 4. RMSE, NMdnB, NMdnE, MdnB and $\mathrm{MdnE}$ for $\mathrm{O}_{3}(\mathrm{ppb})$, fine-particulate mass and species $\left(\mu \mathrm{g} / \mathrm{m}^{3}\right)$, precipitation $(\mathrm{cm})$ and wet deposition species (kg/ha) for August 2006. These metrics are defined in Table 2.

\begin{tabular}{|c|c|c|c|c|c|c|c|c|c|c|c|}
\hline \multirow[t]{2}{*}{ Species } & \multirow[t]{2}{*}{ Network } & \multirow[t]{2}{*}{ \# of Obs } & \multirow[t]{2}{*}{ Mdn of Obs } & \multicolumn{2}{|c|}{ NMdnB (\%) } & \multicolumn{2}{|c|}{ NMdnE (\%) } & \multicolumn{2}{|c|}{ MdnB } & \multicolumn{2}{|c|}{ MdnE } \\
\hline & & & & Base & $\mathrm{v} 4.7$ & Base & $\mathrm{v} 4.7$ & Base & v4.7 & Base & v4.7 \\
\hline $\mathrm{O}_{3}(8-\mathrm{h} \mathrm{Max})$ & AQS & 25920 & 48.4 & 6.9 & 6.9 & 14.7 & 14.5 & 3.32 & 3.35 & 7.13 & 7.02 \\
\hline \multirow{3}{*}{$\mathrm{SO}_{4}^{2-}$} & IMPROVE & 563 & 1.32 & -12.7 & -4.8 & 34.7 & 35.0 & -0.17 & -0.06 & 0.46 & 0.46 \\
\hline & CSN & 963 & 3.51 & -5.0 & -0.2 & 28.3 & 28.0 & -0.18 & -0.01 & 0.99 & 0.98 \\
\hline & CASTNet & 255 & 4.75 & -21.3 & -18.6 & 21.7 & 19.0 & -1.01 & -0.89 & 1.03 & 0.90 \\
\hline \multirow{2}{*}{$\mathrm{NO}_{3}^{-}$} & IMPROVE & 563 & 0.14 & -44.9 & -43.5 & 80.6 & 76.0 & -0.06 & -0.06 & 0.11 & 0.10 \\
\hline & CSN & 918 & 0.39 & -22.0 & -23.8 & 66.6 & 69.4 & -0.09 & -0.09 & 0.26 & 0.27 \\
\hline $\mathrm{TNO}_{3}$ & CASTNet & 255 & 1.64 & 42.3 & 42.3 & 48.5 & 51.1 & 0.69 & 0.69 & 0.79 & 0.84 \\
\hline \multirow{2}{*}{$\mathrm{NH}_{4}^{+}$} & $\mathrm{CSN}$ & 963 & 1.07 & 11.0 & 15.4 & 36.7 & 36.4 & 0.12 & 0.17 & 0.39 & 0.39 \\
\hline & CASTNet & 255 & 1.43 & -9.0 & -6.3 & 16.2 & 16.2 & -0.13 & -0.09 & 0.23 & 0.23 \\
\hline $\mathrm{OC}$ & IMPROVE & 783 & 1.18 & -45.3 & -48.5 & 50.3 & 51.7 & -0.53 & -0.57 & 0.59 & 0.61 \\
\hline EC & IMPROVE & 783 & 0.24 & -30.7 & -31.9 & 39.9 & 40.6 & -0.07 & -0.08 & 0.09 & 0.10 \\
\hline \multirow{2}{*}{$\mathrm{TC}$} & IMPROVE & 783 & 1.47 & -40.5 & -45.2 & 46.5 & 46.9 & -0.60 & -0.66 & 0.68 & 0.69 \\
\hline & CSN & 927 & 3.12 & -31.9 & -35.5 & 39.0 & 40.1 & -1.00 & -1.11 & 1.22 & 1.25 \\
\hline $\mathrm{PM}_{\text {other }}$ & $\mathrm{CSN}$ & 767 & 3.32 & 8.64 & 7.93 & 52.2 & 51.2 & 0.29 & 0.26 & 1.73 & 1.70 \\
\hline \multirow{2}{*}{$\mathrm{PM}_{2.5}$} & IMPROVE & 790 & 6.16 & -28.6 & -28.4 & 37.3 & 37.0 & -1.76 & -1.75 & 2.30 & 2.29 \\
\hline & CSN & 827 & 12.10 & -7.9 & -6.4 & 30.1 & 29.1 & -0.95 & -0.78 & 3.64 & 3.53 \\
\hline Precipitation & \multirow{4}{*}{ NADP } & 193 & 7.24 & -0.6 & & 47.2 & & -0.04 & & 3.42 & \\
\hline WetD Sulf. & & 190 & 1.09 & 8.0 & 8.8 & 32.9 & 34.2 & 0.09 & 0.10 & 0.36 & 0.37 \\
\hline WetD Amm. & & 190 & 0.22 & 3.4 & -1.7 & 39.2 & 39.3 & 0.01 & 0.00 & 0.09 & 0.09 \\
\hline WetD Nitr. & & 190 & 0.83 & -30.2 & -27.1 & 40.9 & 39.7 & -0.25 & -0.22 & 0.34 & 0.33 \\
\hline
\end{tabular}

too much $\mathrm{SO}_{4}^{2-}$ production aloft in the CMAQ model during summer. This bias was identified by Mathur et al. (2008b) based on aircraft measurements of airborne $\mathrm{SO}_{4}^{2-}$ levels collected during the ICARTT field experiment in 2004.

\section{Discussion}

Incremental testing of the CMAQv4.7 model updates allowed for a thorough diagnosis of the causes for changes in model outputs. This is the first time an evaluation of a new CMAQ model version has been approached in this systematic manner. After evaluating each set of model results against ambient measurements collected at several national networks, a number of conclusions have become clear. First, the major inorganic ions in $\mathrm{PM}_{2.5}\left(\mathrm{SO}_{4}^{2-}, \mathrm{NO}_{3}^{-}\right.$and $\left.\mathrm{NH}_{4}^{+}\right)$ which have been the focus of air quality model development efforts over the past several decades are relatively unbiased on a network-wide and monthly-averaged basis. Whereas model developments have historically focused on improving the simulation of summertime air quality, scientific updates in $\mathrm{v} 4.7$ also have improved wintertime predictions of the inorganic ions by a noticeable amount. Given the lack of systematic bias in the model performance for inorganic ions shown in Fig. 10, Tables 3 and 4, future evaluation efforts should test the model results for these species in regional sub-domains (e.g., Fig. 4 by Appel et al., 2008) and during shorter time periods (e.g., episodic high-PM events). Such evaluations may identify areas of poor performance where further model development is warranted.

Second, the predictions of daily-averaged OC and TC show little change despite numerous scientific updates to the SOA treatment in CMAQ v4.7. Although the new SOA module yields better predictions of average wintertime TC in urban areas (Fig. 10) and in the day-versus-night amplitude of TC during summer (Fig. 4), it falls far short of capturing the mean summertime concentrations at either urban or rural locations. Future efforts should focus on identifying and incorporating new SOA formation mechanisms and missing sources of OCs (such as biomass burning, vegetative detritus, pollen fragments, and fungal spores) into CMAQ that will increase model predictions of average summertime OC without erroneously increasing the nighttime or wintertime values. 
Third, it has become apparent that the model biases for total $\mathrm{PM}_{2.5}$ mass during winter are dominated by overpredictions of $\mathrm{PM}_{\mathrm{other}}$. On an absolute scale, the $\mathrm{PM}_{\text {other }}$ model bias greatly exceeds the bias for any other $\mathrm{PM}_{2.5}$ component. None of the scientific updates in $\mathbf{v} 4.7$ were aimed at improving the $\mathrm{PM}_{\text {other }}$ predictions, so it is not surprising that the model predictions show little change between the base model and v4.7. Previous investigators have suggested at least five hypotheses to explain the wintertime $\mathrm{PM}_{\text {other }}$ overpredictions (Appel et al., 2008; Mathur et al., 2008b), and efforts are underway to test them. For example, Reff et al. (2009) recently developed an anthropogenic emissions inventory for $\mathrm{PM}_{2.5}$ trace elements (e.g., $\mathrm{Fe}, \mathrm{Ni}, \mathrm{Zn}$ ) for the US. The CMAQ model will be modified to track several of those trace elements so that the resulting modeled values can be compared against measurements at the national monitoring networks. Such comparisons should shed light on which specific elements or emission sources are contributing most to the wintertime $\mathrm{PM}_{\text {other }}$ bias.

Fourth, we find that the overpredictions of low $\mathrm{O}_{3}$ mixing ratios persist in CMAQv4.7. The tightening of the maximum 8-h $\mathrm{O}_{3}$ National Ambient Air Quality Standard (NAAQS) to a lower threshold value has increased the importance of reducing errors in prediction of these low-moderate $\mathrm{O}_{3}$ mixing ratios. The overprediction of the low end of the $\mathrm{O}_{3}$ range is related to the simulated background concentration, which is largely determined by lateral boundary conditions (LBCs) used in limited area models. Generally, the conditions when low maximum daily 8 -h average $\mathrm{O}_{3}$ occurs are cloudy with strong winds, particularly directed from regions with relatively low $\mathrm{O}_{3}$ mixing ratios, such as oceans or sparsely populated areas, which are often along the model domain boundaries. The nesting of regional and mesoscale model grids within coarser grid resolution global or hemispheric model grids, increased vertical resolution in the lowest model layers, and improvements in representation of exchange processes between the boundary-layer and freetroposphere (cf., Mathur et al., 2005) could help reduce this source of error.

Fifth, errors also persist in prediction of the highest $\mathrm{O}_{3}$ mixing ratios. Conditions for high $\mathrm{O}_{3}$ are generally characterized by high pressure systems that maintain mostly clear skies and inhibit boundary layer growth due to subsidence. Subtle errors in surface conditions (e.g. soil moisture, vegetation type and growth state, or albedo) can lead to errors in PBL depth. Errors in cloud development can cause erroneous PBL development and venting as well as errors in photolysis rates. Errors in wind speed will cause errors in dilution, while errors in wind direction can displace $\mathrm{O}_{3}$ plume maxima. Further improvements in meteorology modeling should reduce many of these errors that contribute to errors in $\mathrm{O}_{3}$ concentration predictions. For example, improved techniques and additional data sources for meteorological data assimilation will reduce errors in wind speed and direction. More accurate high resolution land-use data are being used for the land-surface modeling in WRF and the dry deposition modeling CMAQ. This new database should reduce temperature and humidity errors which will reduce PBL height errors. Updated, more sophisticated microphysics and radiation schemes are now available in the WRF system that reduce errors associated with cloud cover. These efforts will help diagnose the cause of $\mathrm{O}_{3}$ underpredictions at the highest mixing ratios so that the model can be improved and used with greater confidence in developing air quality management plans for peak $\mathrm{O}_{3}$.

Sixth, predictions of the wet deposition species in $\mathrm{v} 4.7$ did not change significantly from the previous version of the model. Predictions of the wet deposition species are highly dependent on the predictions of the aerosol and gas species, as well as to the timing and intensity of precipitation predictions from the meteorological model. Improvements in the predictions of the aerosol and gas species, as well as any improvements in the precipitation and cloud predictions should naturally translate into improved wet deposition predictions. Therefore, the focus in the future will be on improving these predictions first, and then shift to improving the specific wet deposition mechanisms within CMAQ.

Finally, of the five incremental updates discussed here, the changes to the cloud model had the most wide-spread impact on model results, affecting the prediction of $\mathrm{O}_{3}, \mathrm{PM}_{2.5} \mathrm{com}$ ponents and wet deposition. Development of the cloud module will continue to play a critical role in improving these predictions. For example, the current subgrid convective cloud parameterization (included in CMAQv4.7) uses an adaptation of the Asymmetric Convective Model (ACM) (Pleim and Chang, 1992) to mix pollutants vertically in the cloud column. A drawback to this mixing algorithm is that the downdraft is not explicitly simulated. An alternative convective cloud scheme (Grell, 1993) is being incorporated into CMAQ, which will more closely replicate the Grell convective cloud scheme used in WRF. This cloud scheme simulates updrafts, downdrafts, and compensating subsidence/uplifting using a mass-flux scheme and should provide a better representation of the cloud mixing process. Future evaluation of different cloud parameterizations will require vertical profiles of pollutant concentrations from aircraft measurements as well as satellite and radar data on the location and vertical extent of cloud predictions.

Future model evaluation will expand on the results discussed here by utilizing simulations over larger spatial domains and longer time periods. As part of an international model inter-comparison initiative (see http://aqmeii.jrc.ec. europa.eu/aqmeii2.htm), CMAQv4.7 is currently being applied to two domains encompassing the Continental US and Europe for the entire 2006 calendar year. Analysis of model predictions from these applications will provide detailed assessment of model performance for other geographic regions as well as for other seasons. Additionally, the evaluation of the next CMAQ release will include model simulations over a $12 \mathrm{~km}$ continental domain, allowing for analysis of model 
performance for the western United States. Simulations over longer time periods will demonstrate the sensitivity of these model performance results to different meteorological conditions across different seasons.

Acknowledgements. The authors would like to recognize the many contributions of others in the development, testing, and evaluation of CMAQv4.7: Bill Benjey, Russ Bullock, Ann Marie Carlton, Ellen Cooter, Robin Dennis, Steve Howard, Bill Hutzell, Deborah Luecken, Sergey Napelenok, Rob Pinder, George Pouliot, Ken Schere, Donna Schwede, Jenise Swall, Gary Walter, and David Wong (EPA/ORD/NERL/AMAD); Frank Binkowski, Uma Shankar, and Aijun Xiu (University of North Carolina, Institute of the Environment); and Arastoo Pour Biazar (University of Alabama, Huntsville). In addition, we want to thank Lucille Bender, Charles Chang, Ryan Cleary, Allan Huffman, Nancy Hwang, and Lara Reynolds (Computer Sciences Corporation) for their support in processing emissions, performing CMAQ model simulations, and post-processing data for the evaluation.

Disclaimer. The United States Environmental Protection Agency through its Office of Research and Development funded and managed the research described here. It has been subjected to Agency's administrative review and approved for publication.

Edited by: A. Sandu

\section{References}

Aiyyer, A., Cohan, D., Russell, A., Stockwell, W., Tanrikulu, S., Vizuete, W., and Wilczak, J.: Final report: Third peer review of the CMAQ model, online available at: http://www.cmascenter. org/r_and_d/cmaq_review_process.cfm, 2007.

Appel, K. W., Bhave, P. V., Gilliland, A. B., Sarwar, G., and Roselle, S. J.: Evaluation of the Community Multiscale Air Quality (CMAQ) model version 4.5: Sensitivities impacting model performance; Part II - particulate matter, Atmos. Environ., 42, 6057-6066, 2008.

Appel, K. W., Gilliand, A. B., Sarwar, G., and Gilliam, R. C.: Evaluation of the Community Multiscale Air Quality (CMAQ) model version 4.5: Sensitivities impacting model performance, Atmos. Environ., 41, 9603-9615, 2007.

Appel, K. W., Roselle, S. J., Gilliam, R. C., and Pleim, J. E.: Sensitivity of the Community Multiscale Air Quality (CMAQ) model v4.7 results for the eastern United States to MM5 and WRF meteorological drivers, Geosci. Model Dev., 3, 169-188, 2010.

Bash, J. O.: Description and initial simulation of a dynamic bidirectional air-surface exchange model for mercury in CMAQ, J. Geophys. Res., doi:10.1029/2009JD012834, in press, 2010.

Bhave, P. V., Pouliot, G. A., and Zheng, M.: Diagnostic model evaluation for carbonaceous $\mathrm{PM}_{2.5}$ using organic markers measured in the southeastern U.S., Environ. Sci. Technol., 41, 1577-1583, 2007.

Binkowski, F. S., Aranachalam, S., Adelman, Z., and Pinto, J. P.: Examining photolysis rates with a prototype online photolysis module in CMAQ, J. Appl. Meteor. Climatol., 46, 1252-1256, 2007.

Bullock, O. R. and Brehme, K. A.: Atmospheric mercury simulation using the CMAQ model: formulation description and analysis of wet deposition results, Atmos. Environ., 36, 2135-2146, 2002.

Byun, D. and Schere, K. L.: Review of the Governing Equations, Computational Algorithms, and Other Components of the Models-3 Community Multiscale Air Quality (CMAQ) Modeling System, Appl. Mech. Rev., 59, 51-77, 2006.

Carlton, A. G., Bhave, P. V., Napelenok, S. L., Pinder, R. W., Sarwar, G., Pouliot, G. A., and Edney, E. O.: Improved treatment of secondary organic aerosol in CMAQ, Environ. Sci. Technol., in review, 2010.

Carlton, A. G., Turpin, B. J., Altieri, K. E., Seitzinger, S. P., Mathur, R., Roselle, S. J., and Weber, R. J.: CMAQ model performance enhanced when in-cloud secondary organic aerosol is included: comparisons of organic carbon predictions with measurements, Environ. Sci. Technol., 42, 8798-8892, 2008.

Carter, W. P. L.: Implementation of the SAPRC-99 Chemical Mechanism into the Models-3 Framework, Report to the United States Environmental Protection Agency, online available at: http:// www.cert.ucr.edu/ carter/absts.htm\#s99mod3, 2000.

Davis, J. M., Bhave, P. V., and Foley, K. M.: Parameterization of $\mathrm{N}_{2} \mathrm{O}_{5}$ reaction probabilities on the surface of particles containing ammonium, sulfate, and nitrate, Atmos. Chem. Phys., 8, 52955311, 2008, http://www.atmos-chem-phys.net/8/5295/2008/.

Dentener, F. J. and Crutzen, P. J.: Reaction of $\mathrm{N}_{2} \mathrm{O}_{5}$ on tropospheric aerosols: Impact on the global distributions of $\mathrm{NO}_{\mathrm{x}}, \mathrm{O}_{3}$, and $\mathrm{OH}$, J. Geophys. Res., 98(D4), 7149-7163, 1993.

Dickerson, R. R., Kondragunta, S., Stenchikov, G., Civerolo, K. L., Dodderidge, B. G., and Holben, B.: The impact of aerosols on solar UV radiation and photochemical smog, Science, 278, 827830, 1997.

Eder, B. and Yu, S.: A performance evaluation of the 2004 release of Models-3 CMAQ, Atmos. Environ., 40, 4811-4824, 2006.

Edgerton, E. S., Hartsell, B. E., Saylor, R. D., Jansen, J. J., Hansen, D. A., and Hidy, G. M.: The Southeastern Aerosol Research and Characterization Study, part 3: Continuous measurements of fine particulate matter mass and composition, J. Air Waste Manage. Assoc., 56, 1325-1341, 2006.

Environmental Protection Agency: Draft regulatory impact analysis: Changes to renewable fuel standard program, EPA-420-D09-001, 2009.

Evans, M. J. and Jacob, D. J.: Impact of new laboratory studies of $\mathrm{N}_{2} \mathrm{O}_{5}$ hydrolysis on global model budgets of tropospheric nitrogen oxides, ozone and OH, Geophys. Res. Lett., 32, L09813, doi:10.1029/2005GL022469, 2005.

Fann, N., Fulcher, C. M., and Hubbell, B. J.: The influence of location, source, and emission type in estimates of the human health benefits of reducing a ton of air pollution, Air Qual. Atmos. Health, 2, 169-176, 2009.

Foley, K. M., Roselle, S. J., Appel, K. W., Bhave, P. V., Pleim, J. E., Otte, T. L., Mathur, R., Sarwar, G., Young, J. O., Gilliam, R. C., Nolte, C. G., Kelly, J. T., Gilliland, A. B., and Bash, J. O.: Interactive comment on "Incremental testing of the community multiscale air quality (CMAQ) modeling system version 4.7", Geosci. Model Dev. Discuss., 2, C515-C532, 2010a. 
Foley, K. M., Roselle, S. J., Appel, K. W., Bhave, P. V., Pleim, J. E., Otte, T. L., Mathur, R., Sarwar, G., Young, J. O., Gilliam, R. C., Nolte, C. G., Kelly, J. T., Gilliland, A. B., and Bash, J. O. Interactive comment on "Incremental testing of the community multiscale air quality (CMAQ) modeling system version 4.7", Geosci. Model Dev. Discuss., 2, C533-C541, 2010 b.

Frank, N. H.: Retained nitrate, hydrated sulfates, and carbonaceous mass in Federal Reference Method fine particulate matter for six eastern U. S. cities, J. Air Waste Manage. Assoc., 56, 500-511, 2006.

Geron, C.: Carbonaceous aerosol over a Pinus taeda forest in Central North Carolina, USA, Atmos. Environ., 43, 959-969, 2009.

Gilliam, R. C. and Pleim, J. E.: Performance assessment of new land-surface and planetary boundary layer physics in the WRF-ARW, J. Appl. Meteor. Climatol., doi:10.1175/2009JAMC2126.1, in press, 2010.

Graydon, J. A., St. Louis, V. L., Lindberg, S. E., Hintelmann, H., and Krabbenhoft, D. P.: Investigation of mercury exchange between forest canopy vegetation and the atmosphere using a new dynamic chamber, Environ. Sci. Technol. 40, 4680-4688, 2006.

Grell, G. A.: Prognostic evaluation of assumptions used by cumulus parameterizations, Mon. Weather Rev., 121, 764-787, 1993.

Grell, G. A., Dudhia, A. J., and Stauffer, D. R.: A description of the Fifth-Generation PennState/NCAR Mesoscale Model (MM5), NCAR Technical Note NCAR/TN-398+STR, online available at: http://www.mmm.ucar.edu/mm5/doc1.html, 1994.

Guenther, A., Karl, T., Harley, P., Wiedinmyer, C., Palmer, P. I., and Geron, C.: Estimates of global terrestrial isoprene emissions using MEGAN (Model of Emissions of Gases and Aerosols from Nature), Atmos. Chem. Phys., 6, 3181-3210, 2006,

http://www.atmos-chem-phys.net/6/3181/2006/.

Hogrefe, C., Hao, W., Civerolo, K., Ku, J.-Y., Sistla, G., Gaza, R. S., Sedefina, L., Schere, K., Gilliland, A., and Mathur, R.: Daily simulation of ozone and fine particulates over New York state: Findings and Challenges, J. Appl. Meteorol. Climatol., 46, 961979, 2007.

Hutzell, W. T. and Luecken, D. J.: Fate and transport of emissions fro several trace metals over the United States, Sci. Total Environ., 396, 164-179, 2008.

Kelly, J. T., Bhave, P. V., Nolte, C. G., Shankar, U., and Foley, K. M.: Simulating emission and chemical evolution of coarse seasalt particles in the Community Multiscale Air Quality (CMAQ) model, Geosci. Model Dev. Discuss., 2, 1335-1374, 2009.

Kleindienst, T. E., Jaoui, M., Lewandowski, M., Offenberg, J. H., Lewis, C. W., Bhave, P. V., and Edney, E. O.: Estimates of the contributions of biogenic and anthropogenic hydrocarbons to secondary organic aerosol at a southeastern US location, Atmos. Environ., 41, 8288-8300, 2007.

Kurtenbach, R., Becker, K. H., Gomes, J. A. G., Kleffmann, J., Lorzer, J. C., Spittler, M., Wiesen, P., Ackermann, R., Geyer, A., and Platt, U.: Investigations of emissions and heterogeneous formation of HONO in a road traffic tunnel, Atmos. Environ., 35, 3385-3394, 2001.

Lewandowski, M., Jaoui, M., Offenberg, J. H., Kleindienst, T. E., Edney, E. O., Sheesley, R. J., and Schauer, J. J.: Primary and secondary contributions to ambient PM in the Midwestern United States, Environ. Sci. Technol., 42, 3303-3309, 2008.

Luecken, D. J., Hutzell, W. T., and Gipson, G. L.: Development and analysis of air quality modeling simulations for hazardous air pollutants, Atmos. Environ., 40, 5087-5096, 2006.

Mathur, R., Shankar, U., Hanna, A. F., et al: Mutiscale Air Quality Simulation Platform (MAQSIP): Initial applications and performance for tropospheric ozone and particulate matter, J. Geophys. Res., 110, D13308, doi:10.1029/2004JD004918, 2005.

Mathur, R., Roselle, S. J., Pouliot, G. A., and Sarwar, G.: Diagnostic analysis of the three-dimensional sulfur distributions over the eastern United states using the CMAQ model and measurements from the ICARTT field experiment, NATO Science for Peace and Security Series C: Environmental Security, Springer Netherlands, The Netherlands, 496-504, 2008a.

Mathur, R., Yu, S., Kang, D., and Schere, K.: Assessment of the Winter-time Performance of Developmental Particulate Matter Forecasts with the Eta-CMAQ Modeling System, J. Geophys. Res., 113, D02303, doi:10.1029/2007JD008580, 2008b.

Mebust, M. R., Eder, B. K., Binkowski, F. S., and Roselle, S. J.: Models-3 Community Multiscale Air Quality (CMAQ) model aerosol component, J. Geophys. Res., 108(D6), 4184 doi:10.1029/2001JD001410, 2003.

Meng, Z. and Seinfeld, J. H.: Time scales to achieve gas-aerosol equilibrium for volatile species, Atmos. Environ., 30, 28892900, 1996.

Morris, R. E., Koo, B., Guenther, A., Yarwood, G., McNally, D., Tesche, T. W., Tonnesen, G., Boylan, J., and Brewer, P.: Model sensitivity evaluation for organic carbon using two multipollutant air quality models that simulate regional haze in the southeastern United States, Atmos. Environ., 40, 4960-4972, 2006.

Nolte, C. G., Bhave, P. V., Arnold, J. R., Dennis, R. L., Zhang, K. M., and Wexler, A. S.: Modeling urban and regional aerosols - Application of the CMAQ-UCD aerosol model to Tampa, a coastal urban site, Atmos. Environ., 42, 3179-3191, 2008a.

Nolte, C. G., Gilliland, A. B., Hogrefe, C., and Mickley, L. J.: Linking global to regional models to assess future climate impacts on surface ozone levels in the United States, J. Geophys. Res., 113, D14307, doi:10.1029/2007JD008497, 2008b.

Nolte, C. G., Roselle, S. J., and Binkowski, F. S.: Implementation of an Online Photolysis Module in CMAQ 4.7. 7th CMAS Conference, Chapel Hill, NC, 6-8 October, online available at: http://www.cmascenter.org, 2008c.

Offenberg, J. H., Kleindienst, T. E., Jaoui, M., Lewandowski, M., and Edney, E. O.: Thermal properties of secondary organic aerosols, Geophys. Res. Lett., 33, L03816, doi:10.1029/2005GL024623, 2006.

Otte, T. L.: The impact of nudging in the meteorological model for retrospective air quality simulations. Part I: Evaluation against national observation networks, J. Appl. Meteor. Climatol., 47, 1853-1867, 2008a.

Otte, T. L.: The impact of nudging in the meteorological model for retrospective air quality simulations. Part II: Evaluating collocated meteorological and air quality observations, J. Appl. Meteor. Climatol., 47, 1868-1887, 2008b.

Otte, T. L. and Pleim, J. E.: The Meteorology-Chemistry Interface Processor (MCIP) for the CMAQ modeling system, Geosci. Model Dev. Discuss., 2, 1449-1486, 2009.

Pleim, J. E.: A combined local and nonlocal closure model for the atmospheric boundary layer. Part I: Model description and testing, J. Appl. Meteor. Climatol., 46, 1383-1395, 2007. 
Pleim, J. E. and Chang, J. S.: A non-local closure model for vertical mixing in the convective boundary layer, Atmos. Environ., 26, 965-981, 1992.

Pleim, J. E. and Gilliam, R.: An indirect data assimilation scheme for deep soil temperature in the Pleim-Xiu land surface model, J. Appl. Meteor. Climatol., 48, 1362-1376, 2009.

Pleim, J. E., Roselle, S. J., Bhave, P. V., Bullock, O. R., Hutzell, W. T., Luecken, D. J., Nolte, C. G., Sarwar, G., Schere, K. L., Young, J., Godowitch, J., and Appel, K. W.: The 2006 CMAQ Release and Plans for 2007, Extended abstract for the 5th CMAS Conference, Chapel Hill, NC, available at: http://www.cmascenter.org, 16-18 October 2006.

Pleim, J. E. and Xiu, A.: Development of a land surface model. Part II: Data Assimilation, J. Appl. Meteor., 42, 1811-1822, 2003.

Pour-Biazar, A., McNider, R. T., Roselle, S. J., Suggs, R., Jedlovec, G., Byun, D. W., Kim, S., Lin, C. J., Ho, T. C., Haines, S., Dornblaser, B., and Cameron, R.: Correcting photolysis rates on the basis of satellite observed clouds, J. Geophys. Res., 112, D10302, doi:10.1029/2006JD007422, 2007.

Pryor, S. C. and Sørensen, L. L.: Nitric acid-sea salt reactions: Implications for nitrogen deposition to water surfaces, J. Appl. Meteor., 39, 725-731, 2000.

Reff, A., Bhave, P. V., Simon, H., Pace, T. G., Pouliot, G. A., Mobley, J. D., and Houyoux, M.: Emissions inventory of $\mathrm{PM}_{2.5}$ trace elements across the United States, Environ. Sci. Technol., 43(15), 5790-5796, 2009.

Riemer, N., Vogel, H., Vogel, B., Schell, B., Ackermann, I., Kessler, C., and Hass, H.: Impact of the heterogeneous hydrolysis of $\mathrm{N}_{2} \mathrm{O}_{5}$ on chemistry and nitrate aerosol formation in the lower troposphere under photosmog conditions, J. Geophys. Res., 108, 4144, doi:10.1029/2002JD002436, 2003.

Roselle, S. J., Luecken, D. J., Hutzell, W. T., Bullock, O. R., Sarwar, G., and Schere, K. L.: Development of a Multipollutant Version of the Community Multiscale Air Quality (CMAQ) Modeling System, Extended abstract for the 6th CMAS Conference, Chapel Hill, NC, available at: http://www.cmascenter.org, 1-3 October, 2007.

Sarwar, G., Luecken, D., Yarwood, G.: Developing and implementing an updated chlorine chemistry into the Community Multiscale Air Quality Model. Chapter 2, in: Air Pollution Modeling and its Applications XVIII, edited by: Borrego C. and Renner E., Elsevier, The Netherlands, 168-176, 2007.

Sarwar, G., Roselle, S., Mathur, R., Appel, W., Dennis, R., and Vogel, B.: A Comparison of CMAQ HONO predictions with observations from the northeast oxidant and particle study, Atmos. Environ., 42, 5760-5770, 2008.
Scheffe, R., Hubbell, B., Fox, T., Rao, V., and Pennell, W.: The rationale for a multipollutant, multimedia air quality management framework, EM Magazine, 14-20 May 2007.

Schwede, D., Pouliot, G. A., and Pierce, T.: Changes to the Biogenic Emissions Inventory System Version 3 (BEIS3), In Proceedings of the 4th CMAS Models-3 Users' Conference, Chapel Hill, NC, available at: , 26-28 September 2005.

Sheehan, P. E. and Bowman, F. M.: Estimated effects of temperature on secondary organic aerosol concentrations, Environ. Sci. Technol., 35, 2129-2135, 2001.

Simon, H., Kimura, Y., McGaughey, G., Allen, D. T., Brown, S. S., Osthoff, H. D., Roberts, J. M., Byun, D., and Lee, D.: Modeling the impact of $\mathrm{ClNO}_{2}$ on ozone formation in the Houston area, J. Geophys. Res., 114, D00F03, doi:10.1029/2008JD010732, 2009.

Skamarock, W. C., Klemp, J. B., Dudhia, J., Gill, D. O., Barker, D. M., Duda, M., Huang, X.-Y., Wang, W., and Powers, J. G.: A Description of the Advanced Research WRF Version 3, NCAR Technical Note, NCAR/TN-468+STR, available at: http://wrf-model.org/wrfadmin/docs/arw_v2.pdf, 2008.

Sutton, M. A., Burkhardt, J. K., Guerin, D., Nemitz, E., and Fowler, D.: Development of resistance models to describe measurements of bi-directional ammonia surface-atmosphere exchange, Atmos. Environ., 32, 473-480, 1998.

Van Heuklon, T. K.: Estimating atmospheric ozone for solar radiation models, Sol. Energy, 22, 63-68, 1979.

Vukovich, J. and Pierce, T.: The Implementation of BEIS3 within the SMOKE Modeling Framework, in: Proceedings of the 11th International Emissions Inventory Conference, Atlanta, Georgia, available at: www.epa.gov/ttn/chief/conference/ei11/modeling/ vukovich.pdf, 15-18 April 2002.

Xiu, A. and Pleim, J. E.: Development of a land surface model. Part I: Application in a mesoscale meteorology model, J. Appl. Meteor., 40, 192-209, 2001.

Yarwood, G., Rao, S., Yocke, M., and Whitten, G.: Updates to the Carbon Bond chemical mechanism: CB05. Final report to the US EPA, RT-0400675, available at http://www.camx.com/publ/pdfs/ CB05_Final_Report_120805.pdf, 2005.

Yu, S., Bhave, P. V., Dennis, R. L., and Mathur, R.: Seasonal and regional variations of primary and secondary organic aerosols over the continental United States: Semi-empirical estimates and model evaluation, Environ. Sci. Technol., 41, 4690-4697, 2007. 